\title{
Hawksbill sea turtle life-stage durations, somatic growth patterns, and age at maturation
}

\author{
Larisa Avens $^{1, *}$, Matthew D. Ramirez ${ }^{2}$, Lisa R. Goshe ${ }^{1}$, Jamie M. Clark $^{1,3}$, \\ Anne B. Meylan ${ }^{4}$, Wendy Teas ${ }^{5}$, Donna J. Shaver ${ }^{6}$, Matthew H. Godfrey ${ }^{7,8,9}$, \\ Lyndsey Howell ${ }^{10}$
}

${ }^{1}$ National Marine Fisheries Service, Southeast Fisheries Science Center, NOAA Beaufort Laboratory, Beaufort, NC 28516, USA
${ }^{2}$ University of Rhode Island, Graduate School of Oceanography, Narragansett, RI 02882, USA
${ }^{3}$ Riverside Technology, Inc., Beaufort, NC 28516, USA
${ }^{4}$ Florida Fish and Wildlife Conservation Commission, Fish and Wildlife Research Institute, St. Petersburg, FL 33701, USA
${ }^{5}$ National Marine Fisheries Service, Southeast Fisheries Science Center, Miami, FL 33149, USA
${ }^{6}$ National Park Service, Padre Island National Seashore, Corpus Christi, TX 78418, USA
${ }^{7}$ North Carolina Wildlife Resources Commission, Beaufort, NC 28516, USA
${ }^{8}$ Duke Marine Laboratory, Nicholas School of Environment, Duke University, Beaufort, NC 28516, USA
${ }^{9}$ Department of Clinical Sciences, College of Veterinary Medicine, North Carolina State University, Raleigh, NC 27607, USA
${ }^{10}$ National Marine Fisheries Service, Office of Protected Resources, NOAA Pascagoula Laboratory, Pascagoula, MS 39567, USA

ABSTRACT: Sea turtles exhibit complex life histories, encompassing intermittent use of multiple spatially separated habitats throughout long lifespans. This broad scope presents challenges for collecting comprehensive biological and ecological data, yet absence of such information complicates evaluation of management strategies for populations at risk of extinction. Hawksbill sea turtles Eretmochelys imbricata are endangered worldwide, primarily due to long-term, directed harvest. However, available information regarding life stage durations, somatic growth patterns, and maturation attributes to enhance understanding of anthropogenic impacts and recovery potential remains constrained. To address these data gaps in the western North Atlantic, we conducted skeletochronological analysis for hawksbills stranded along US coastlines to generate straightline carapace length (SCL)-at-age and somatic growth data. Generalized additive mixed models and bootstrapped von Bertalanffy growth curves were used to characterize age at maturation and covariate influence on somatic growth. For a subset of turtles, annual bone growth incrementspecific stable isotope and trace element analyses were incorporated to evaluate habitat use relative to age. Integration of these data sources indicated that juveniles transitioned from oceanic to neritic habitat at 1-3 yr old and mean SCLs of 23-24 cm (range 15.7-35.0 cm). Initial ages at maturation for this population at minimum nesting female SCLs were estimated at 15-25 yr. Somatic growth varied significantly relative to size, age, and stranding location, while no association with sex or calendar year was observed. Our results demonstrate the utility of these complementary analytical approaches for generating baseline data fundamental to characterizing hawksbill sea turtle population attributes.

KEY WORDS: Eretmochelys imbricata $\cdot$ Nitrogen isotope $\cdot$ Carbon isotope $\cdot$ Strontium $\cdot$ Barium Atlantic Ocean · Gulf of Mexico

\section{INTRODUCTION}

Although the global distribution of the hawksbill sea turtle Eretmochelys imbricata is predominantly centered in tropical waters, its range in the western

*Corresponding author: Larisa.Avens@noaa.gov
North Atlantic also extends into sub-tropical areas along the US Gulf of Mexico (GoM) and Atlantic coasts (Wallace et al. 2010; Fig. 1). Within the continental USA, nesting has been characterized as rare in the state of Florida, with $0-5$ nests recorded per

(1) M. D. R., J. M. C., A. B. M., M. H. G., and outside the USA, the US Government 2021. Open Access under Creative Commons by Attribution Licence. Use, distribution and reproduction are unrestricted. Authors and original publication must be credited.

Publisher: Inter-Research · www.int-res.com 


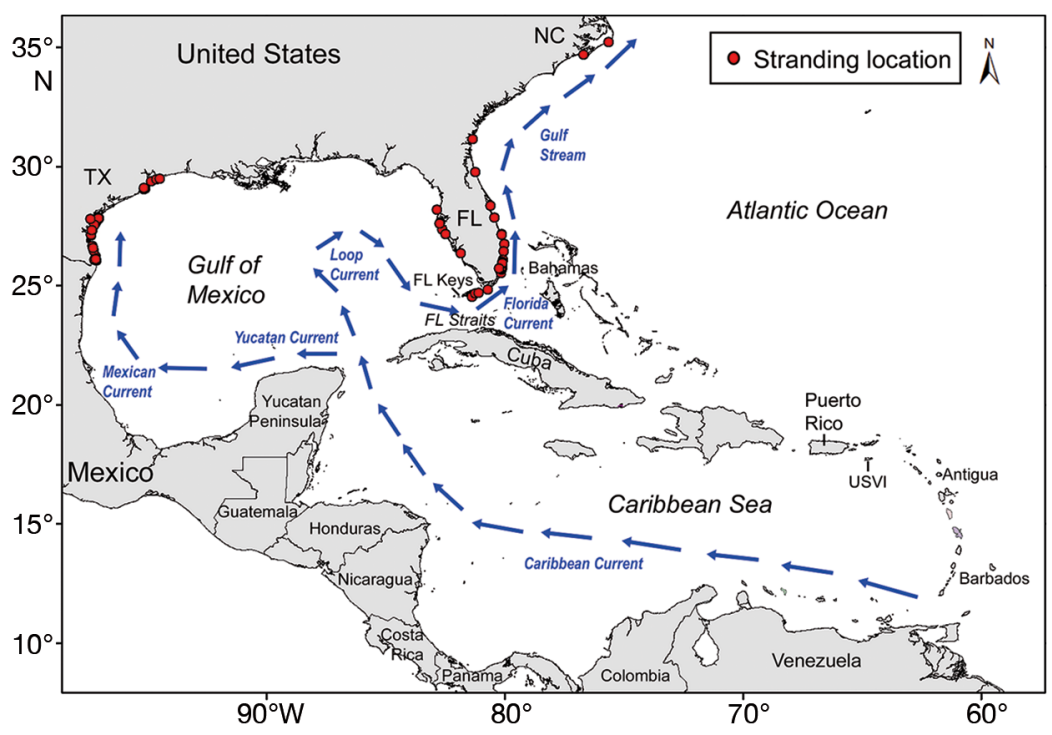

Fig. 1. Spatial characteristics relevant for the current study within the geographic range occupied by the NW Atlantic hawksbill sea turtle population. Generalized oceanic current paths are delineated by blue arrows. Red dots: stranding locations for turtles from which samples were collected (overlapping in many cases, due to stranding density relative to map scale).

TX: Texas; FL: Florida; NC: North Carolina; USVI: US Virgin Islands

stranding locations may be more reflective of nearby habitat use (Meylan \& Redlow 2006). In fact, in Florida, hawksbills regularly occur in nearshore waters off the southeastern coast, in the Florida Keys (including the Marquesas and Dry Tortugas) and in GoM waters off the west-central coast; however, they are rarely encountered along the upper northwest coast or in northeastern Florida (reviewed by Meylan \& Redlow 2006). In-water survey, power plant entrapment, museum, cold-stunning, and incidental capture records in Florida have documented the regular presence of juvenile and, in some cases, adult-sized hawksbills (Meylan \& Redlow 2006, Eaton et al. 2008, Hart et al. 2013, Wood et al. 2013, Gorham et al. 2014, Herren et al. 2018). Individuals in several foraging areas in Florida as well as the US Virgin Islands have also exhibited site fidelity and extended residency over pe-

year from 1979 to 2019 (Florida Fish and Wildlife Conservation Commission, Statewide Nesting Beach Survey Database, see https://myfwc.com/research/ wildlife/sea-turtles/nesting/monitoring/) and as very rare in Texas over a comparable time span (i.e. a single documented nest, Shaver \& Frandsen 2019). The only other confirmed hawksbill nesting in the southeastern US involved a single female that deposited 2 clutches in North Carolina in 2015 (Finn et al. 2016). Hawksbill distribution in the mainland US is most extensively documented through records of individuals washing ashore (i.e. stranding), and these reports also show that the species is observed with regularity along the coasts of Texas and Florida, but with sporadic, minimal reports from all other US GoM and Atlantic states (Sea Turtle Stranding and Salvage Network [STSSN] unpubl. data). Stranding records also indicate regional differences in size distribution, with a larger proportion of post-hatchling hawksbills being recovered in Texas waters (Amos 1989, Shaver 1998), and a broader size range documented for Florida (Meylan \& Redlow 2006). In contrast to this relatively limited mainland distribution, US territories such as Puerto Rico and the US Virgin Islands in the Caribbean Sea host more extensive foraging and reproductive aggregations (NMFS \& USFWS 2013).

Relative to other stranded sea turtle species, a greater proportion of hawksbills are recovered alive in the mainland USA, leading to the suggestion that riods of more than $1 \mathrm{yr}$ (Hart et al. 2012, 2013, Wood et al. 2013, Gorham et al. 2014, Herren et al. 2018). Although far less information is available to describe inwater distribution in Texas, juvenile hawksbills have been seen along jetties near Port Aransas (Rabalais \& Rabalais 1980), and 2 were captured in Mansfield Channel (Shaver 1994, D. J. Shaver unpubl. data). In addition, hawksbills are regularly observed at coral reefs at the Flower Garden Banks National Marine Sanctuary in the western GoM, approximately 200 $\mathrm{km}$ south of the Texas/Louisiana state border (Office of National Marine Sanctuaries 2008).

Given the paucity of hawksbill nesting in the mainland USA, spatial patterns of juvenile size distributions and relative occurrence in US waters are thought to reflect differential dispersal and recruitment. Genetic data indicate recruitment predominantly from nesting beaches on the Yucatan Peninsula in Mexico, particularly for hawksbills found in Texas (Bowen et al. 2007), but also from other populations including Barbados, Costa Rica, Cuba, Puerto Rico, Antigua, and the US Virgin Islands (Meylan \& Redlow 2006, Blumenthal et al. 2009, Wood et al. 2013, Gorham et al. 2014; Fig. 1). Similar to earlystage juveniles of other cheloniid sea turtle species, hawksbills initially inhabit epi-pelagic Sargassum macroalgae communities in the oceanic environment (Carr 1987, Witherington et al. 2012). As part of this association, hatchlings and post-hatchlings from 
Mexico and nesting beaches farther south are carried by currents into the GoM where the Loop Current has a strong and variable influence, potentially bringing them to Texas, or eventually taking them eastward through the Florida Straits (Meylan \& Redlow 2006). In contrast, post-hatchlings from the eastern Caribbean may reach Florida via the Antilles Current (Meylan \& Redlow 2006). In either case, early-stage hawksbills may continue northward in the Florida Current (which transitions to the Gulf Stream) and recruit to neritic foraging areas along the southeastern Florida coast. Overall, the distribution of neritic hawksbills in Florida closely corresponds to the location of the Florida Reef Tract, which extends northward along the east coast to a latitude of approximately $27^{\circ} \mathrm{N}$, as well as to other hard-bottom communities off the southwest coast (Meylan \& Redlow 2006).

Globally, all hawksbill sea turtle populations, including those in the western North Atlantic, are considered Critically Endangered (Mortimer \& Donnelly 2008, NMFS \& USFWS 2013). These populations remain depleted relative to historic abundances due not only to cumulative impacts of the types of myriad threats that affect sea turtles overall (e.g. bycatch, entanglement, habitat degradation, pollution [especially oil and plastics], egg poaching), but also to long-term, directed harvest of individuals for commercial sale of their scutes as 'tortoiseshell' (Meylan \& Donnelly 1999). Encouraging signs of increased nesting numbers have been reported for some western North Atlantic populations (e.g. GarduñoAndrade et al. 1999, Beggs et al. 2007, van Dam et al. 2008, Kendall et al. 2019), yet recovery objectives for the species in this region have not been met as of the most recent completed status review (NMFS \& USFWS 2013). To facilitate conservation and management efforts integral to the persistence of the population, comprehensive biological and ecological data are essential. Study of juvenile hawksbills has recently been identified as a global priority within the overall scope of sea turtle-related research (Wildermann et al. 2018). In addition, as for any species, an understanding of mean and variability in age at sexual maturation (ASM) is needed to accurately model hawksbill population dynamics and anticipate outcomes of management actions (Crouse 1999, NRC 2010).

With respect to the western North Atlantic hawksbill population, mark-recapture studies have been conducted for a number of neritic foraging aggregations in the Caribbean and South America (Boulon 1994, León \& Diez 1999 Diez \& van Dam 2002, Blu- menthal et al. 2009, Bjorndal \& Bolten 2010, Krueger et al. 2011, Hart et al. 2013, Gorham et al. 2014, Hawkes et al. 2014, Bjorndal et al. 2016, Bellini et al. 2019, Santos et al. 2019), as well as along the Florida Atlantic coast (Wood et al. 2013) and in the Florida Keys (Gorham et al. 2014, Herren et al. 2018). These studies have yielded valuable somatic growth data that can be used to make inferences regarding the duration of the neritic juvenile life stage and evaluate spatial and temporal trends in somatic growth. However, estimates of ASM remain uncertain because data are lacking to determine the duration of the oceanic stage preceding neritic recruitment (Diez \& van Dam 2002, Bjorndal \& Bolten 2010, Bellini et al. 2019, Moncada et al. 2020). Furthermore, compilation of region-wide neritic growth data has also indicated long-term declines in somatic growth rates potentially due to climate-related changes in ecosystem productivity (Bjorndal et al. 2016), which could increase variability in ASM. As a result, collection of additional, broad-scale data would be beneficial for continuing to characterize general patterns and trends in somatic growth and ASM, as well as to improve understanding of the role of US waters as feeding and developmental habitat for hawksbill aggregations.

In recent years, advances have been made in application and validation of skeletal growth-mark analysis (i.e. skeletochronology) for estimating ages and somatic growth rates using bones of stranded, dead sea turtles, including hawksbills (reviewed by Avens \& Snover 2013, Snover et al. 2013). Through collaboration with stranding response networks (e.g. STSSN), it has been possible to collect sea turtle bones across large areas over long time periods, allowing characterization of size-at-age relationships and somatic growth patterns spanning decades (e.g. Avens et al. 2015, 2017, 2020a,b, Ramirez et al. 2020a,b). Furthermore, refinement of methods to conduct annual skeletal growth increment-specific stable isotope and trace element analyses have made it possible to integrate information about habitat use with age and somatic growth data to define life stage durations (Ramirez et al. 2015, Turner Tomaszewicz et al. 2015, 2017, 2018, Avens et al. 2020b).

Here, we applied this integrated approach for the first time to hawksbill sea turtles in the western North Atlantic. First, we analyzed complementary skeletochronology, stable isotope, and trace element data to characterize the mean and variability surrounding age at oceanic to neritic transition in this region. In addition, we modeled the skeletochronology age and growth data alone to estimate ASM for 
this sub-set of the hawksbill population. Finally, the skeletochronology data were used to characterize somatic growth rates and patterns for turtles inhabiting US waters.

\section{MATERIALS AND METHODS}

\subsection{Sample collection and preparation}

We coordinated with the national STSSN along the US Atlantic and GoM coasts to collect a front flipper from hawksbill sea turtles that washed ashore dead, or were debilitated and later died. Associated information included stranding date and location, and a measurement of carapace length (straight line from the nuchal notch to posterior tip; SCL). In cases where only curved carapace length (CCL) measurements were available, both for turtles from which samples were collected and where conversions of measurement data from other studies were needed for comparison, the following equations from Bjorndal et al. (2016, their Table S1, https://esajournals. onlinelibrary.wiley.com/action/downloadSupplement? doi=10.1002 \% 2Fecs2.1279\&file=ecs21279-sup-0001AppendixS1.pdf) were applied:

$$
\begin{aligned}
\mathrm{SCL}_{\text {notch-tip }} & =0.9326 \times \mathrm{CCL}_{\text {notch-tip }} \\
& +0.4496\left(\text { adjusted } \mathrm{R}^{2}=0.9971\right) \\
\mathrm{SCL}_{\text {notch-tip }} & =0.9708 \times \mathrm{CCL}_{\text {notch-notch }} / \mathrm{min} \\
& +0.4336\left(\text { adjusted } \mathrm{R}^{2}=0.9948\right)
\end{aligned}
$$

When possible, sex of stranded turtles was determined via examination of gonads during necropsy. Humerus bones were subsequently dissected away from surrounding tissue and prepared for further analysis according to the methods described by Avens \& Snover (2013). Briefly, each humerus was boiled to remove soft tissue and then allowed to dry for several weeks. A low-speed saw and diamond wafering blade were then used to cut 2 sequential cross-sections from the narrowest point of the diaphysis, with one section to be used for skeletochronology and the other for stable isotope and trace element analyses.

Each skeletochronology humerus section was fixed and decalcified using a commercially available solution (Cal-Ex II), after which $25 \mu \mathrm{m}$ thin sections were cut using a freezing stage microtome (Leica). Thin sections were stained using modified Ehrlich's hematoxylin, and the section exhibiting optimal tissue integrity and staining consistency was mounted in $100 \%$ glycerin using glass microscope slides and cover slips. Sequential, partial images of each thin section were taken at $4 \times$ magnification using a compound microscope, digital camera, and image acquisition software and then re-combined into a mosaic using Adobe Photoshop software to form a calibrated digital image of the entire humerus section. A minimum of 2 individuals (L.A., L.R.G., and/or J.M.C.) conducted independent evaluation of the number and placement of the lines of arrested growth (LAGs) that delimit the outer edges of individual skeletal growth marks within each humerus section image. Once consensus was reached, diameter measurements were taken of every LAG for which both lateral edges were visible, as well as of the entire humerus section.

\subsection{Age estimation}

Characterization of age using skeletal growth mark counts relies on knowledge of early LAG appearance and deposition patterns, including the frequency with which LAGs form. The earliest LAG deposited in sea turtle bones has been described as a diffuse 'annulus' that manifests during the first late winter/early spring of an individual's life at an approximate age of 0.75 yr (Snover \& Hohn 2004, Avens et al. 2013). Snover et al. (2013) analyzed humeri of hawksbill sea turtles stranded in Hawaii and observed the presence of a first-year annulus. During initial evaluation of humerus sections from small juveniles in the current study, we also noted diffuse marks consistent in appearance with firstyear annuli, and therefore assigned an age of $0.75 \mathrm{yr}$ to these LAGs as a starting point for calculating age. Furthermore, Snover et al. (2013) were able to indirectly validate annual LAG deposition, providing further support for application of skeletochronological analysis for hawksbills in a manner similar to other cheloniid species (e.g. Avens et al. 2012, 2015, 2017 , Turner Tomaszewicz et al. 2015).

In the bones of larger sea turtles, the earliest LAGs (such as the annulus) can be destroyed, or resorbed, due to developmental changes in core bone morphology (Zug et al. 1986). Resorption of early LAGs then necessitates development and application of models ('correction factors') to estimate the number of LAGs missing in bones where the annulus is not visible. As in previous studies (e.g. Avens et al. 2012, 2015, 2017), we developed a stepwise correction factor for western North Atlantic hawksbills by modeling the relationship between LAG number and LAG diameter, starting with the annulus. For this population, the 
relationship was best represented by a second-order polynomial, where $y$ is LAG diameter and $x$ is LAG number:

$$
y=-0.0526 x^{2}+2.2641 x+2.8658\left(R^{2}=0.91\right)
$$

Resorption core diameter was then incorporated into the model in place of LAG diameter to predict the number of lost LAGs, which was then added to the number of observed LAGs to yield a total age estimate for each turtle. This age estimate was then adjusted to the nearest $0.25 \mathrm{yr}$ based on stranding date relative to hatch date for the primary presumptive source population. Specifically, genetic data indicate that the majority of juvenile hawksbills foraging in mainland US coastal waters originate from Mexico (Bowen et al. 2007, Wood et al. 2013) where the mid-point of the nesting season occurs in July. Given an incubation period of $\sim 60 \mathrm{~d}$ (Kamel 2013), the mid-point of the hatching season would therefore occur during September. An age estimate was also assigned to all visible LAGs within each humerus sample, based on the starting point of $0.75 \mathrm{yr}$ for the annulus (i.e. subsequent LAGs would represent ages of $1.75,2.75,3.75 \ldots$ etc.). In addition, each LAG was assigned a calendar year relative to the year of stranding.

\subsection{Somatic growth rate calculation}

To make inferences regarding somatic growth from bone growth when applying skeletochronology to cheloniid sea turtles, it is first necessary to determine the relationship between the relevant bone measure (humerus section diameter; HSD) and somatic measure (carapace length, in this case SCL) (Snover et al. 2007). Similar to previous studies involving other cheloniid species, we found close correspondence between these measures for western North Atlantic hawksbill sea turtles, and the relationship was best characterized as allometric (e.g. Avens et al. 2012, 2015, 2017). Integration of the body proportional hypothesis that accounts for individual variability in the HSD and SCL relationship with the allometric equation yielded the following equation that was then used to predict SCL for every measurable LAG in each humerus (Snover et al. 2007):

$$
\begin{aligned}
L_{\text {initial }} & =\left[L_{\mathrm{op}}+b\left(D_{\text {initial }}-D_{\mathrm{op}}\right)^{c}\right] \times\left[L_{\text {final }}\right] \\
& \times\left[L_{\mathrm{op}}+b\left(D_{\text {final }}-D_{\mathrm{op}}\right)^{c}\right]^{-1}
\end{aligned}
$$

where $L_{\text {initial }}$ is the estimated initial SCL for the growth increment; $L_{\mathrm{op}}$ is the minimum hatchling SCL for the study population $(4.1 \mathrm{~cm}) ; b$ is the slope of the relationship (3.81); $D_{\text {initial }}$ is the initial LAG diameter for the growth increment; $D_{\text {op }}$ is the minimum hatchling HSD for the study population $(1.79 \mathrm{~mm}) ; C$ is the proportionality coefficient $(0.87) ; L_{\text {final }}$ is the SCL at stranding; and $D_{\text {final }}$ is the HSD at stranding.

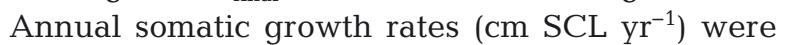
calculated by taking the difference between successive SCLs estimated from LAG diameters throughout each humerus section. Somatic growth rate for the first year of life was estimated by taking the difference between SCL estimated for the annulus and minimum hatchling SCL available for the species in this region (4.1 cm; van Buskirk \& Crowder 1994). Resulting growth rates were then binned by $10 \mathrm{~cm}$ SCL size classes to facilitate comparison with data presented similarly in the published literature. Each growth rate data point was also related to the mean SCL for the increment, as well as age estimate and calendar year associated with the LAG representing the beginning of the increment. In addition, for a subset of the turtles, necropsy data made it possible to differentiate between growth increments associated with males and females, vs. turtles of unknown sex.

\subsection{Characterizing oceanic to neritic habitat shift}

We used 2 complementary approaches, stable isotope and trace element analysis, together with skeletochronology to reconstruct hawksbill sea turtle ontogenetic habitat shifts and quantify oceanic stage duration. Previous research has demonstrated that stable nitrogen isotope $\left(\delta^{15} \mathrm{~N}\right)$ values increase substantially within the tissues of loggerhead Caretta caretta and Kemp's ridley Lepidochelys kempii sea turtles throughout the western North Atlantic Ocean (i.e. US Atlantic and GoM for Kemp's ridleys and US Atlantic for loggerheads) following their oceanic-toneritic habitat transition, due to coupled shifts in nitrogen cycling at the base of occupied food webs (oceanic: $\mathrm{N}_{2}$-fixation, neritic: denitrification) and changes in diet (Snover 2002, Snover et al. 2010, Avens et al. 2013, 2020b, Goodman Hall et al. 2015, Ramirez et al. 2015, 2019, Bean \& Logan 2019). Although the causal mechanisms remain unclear, barium to calcium (Ba:Ca) and strontium to calcium (Sr:Ca) ratios appear to also track changes in oceanic vs. neritic resource use in these species in the GoM and along the US Atlantic (Ramirez et al. 2019). Importantly, Ba:Ca and $\mathrm{Sr}$ :Ca ratios may provide a better tool for studying ontogenetic shifts in turtles that occupy neritic habitats in south Florida or the West 
Florida Shelf, where $\delta^{15} \mathrm{~N}$ values may less reliably reveal oceanic-to-neritic habitat shifts. Specifically, the presence of the $\mathrm{N}_{2}$-fixing cyanobacterium Trichodesmium along the West Florida Shelf reduces baseline $\delta^{15} \mathrm{~N}$ values such that they are more similar to those found in oceanic habitats of the GoM than the average coastal marine habitat (e.g. Ceriani et al. 2014, Vander Zanden et al. 2015).

To collect bone dust for isotopic analysis, we used a computer-guided micromill (ESI New Wave Research) to sample the annual humerus bone growth layers of turtles that stranded along the Florida $(\mathrm{n}=25)$ and Texas $(\mathrm{n}=21)$ coastlines. Bone dust $(\sim 1.6 \mathrm{mg})$ was analyzed for $\delta^{15} \mathrm{~N}$ and $\delta^{13} \mathrm{C}$ values by a continuous-flow isotope-ratio mass spectrometer at Oregon State University. Stable isotope ratios of samples relative to the standard are presented in the standard delta $(\delta)$ notation $\left[\delta X=\left(R_{\text {sample }} / R_{\text {standard }}\right)-1\right]$, where $X$ is ${ }^{15} \mathrm{~N}$ or ${ }^{13} \mathrm{C}$ and $R$ is the ratio of heavy to light isotopes $\left({ }^{15} \mathrm{~N} /{ }^{14} \mathrm{~N}\right.$ or $\left.{ }^{13} \mathrm{C} /{ }^{12} \mathrm{C}\right)$ in the sample and standard, respectively. $R_{\text {standard }}$ was atmospheric $\mathrm{N}_{2}$ for $\delta^{15} \mathrm{~N}$ and Vienna Pee Dee Belemnite for $\delta^{13} \mathrm{C}$. The internal standard IAEA-600 (caffeine; isotopic composition of $\delta^{15} \mathrm{~N}=1.00 \%$ and $\delta^{13} \mathrm{C}=-27.77 \%$ ) was calibrated at regular intervals against the international standards. Analytical precision was $0.09 \%$ for $\delta^{15} \mathrm{~N}$ and $0.07 \%$ for $\delta^{13} \mathrm{C}$. C: $\mathrm{N}$ ratios $(\% \mathrm{C}$ divided by $\% \mathrm{~N}$ ) calculated using mass 28 and mass 44 were below 3.5, characteristic of unaltered protein with low lipid content (Koch et al. 1994, Post et al. 2007). $\delta^{13} \mathrm{C}$ data were not included in the analysis but are presented uncorrected, along with the $\delta^{15} \mathrm{~N}$ data in Table S1 in Supplement 1 at www.int-res.com/articles/ suppl/n045p127_supp1.xlsx.

Trace element ratios were collected via laser ablation-inductively coupled plasma-mass spectrometry (LA-ICP-MS) following Ramirez et al. (2019). Briefly, bone cross-sections were polished, cleaned ultrasonically, and then mounted onto glass slides. We then used a Thermo Elemental X-series II ICP-MS coupled with a New Wave DUV193 excimer laser to collect counts of ${ }^{25} \mathrm{Mg},{ }^{43} \mathrm{Ca},{ }^{51} \mathrm{~V},{ }^{52} \mathrm{Cr},{ }^{55} \mathrm{Mn},{ }^{59} \mathrm{Co},{ }^{60} \mathrm{Ni}$, ${ }^{65} \mathrm{Cu},{ }^{66} \mathrm{Zn},{ }^{86} \mathrm{Sr},{ }^{112} \mathrm{Cd},{ }^{138} \mathrm{Ba}$, and ${ }^{206-208} \mathrm{~Pb}$ (Oregon State University WM Keck Collaboratory for Plasma Spectrometry, Corvallis, OR). All samples were ablated along a transect running from the interior of the bone (older growth layers) to the exterior of the bone (newer growth layers; pulse rate: $5 \mathrm{~Hz}$, spot size: $85 \mu \mathrm{m}$, travel time: $15 \mu \mathrm{m} \mathrm{s}^{-1}$ ). Prior to data collection, samples were pre-ablated to remove surface contamination along the ablation transect $(2 \mathrm{~Hz}$, spot size: $100 \mu \mathrm{m})$. Count rates were normalized to ${ }^{43} \mathrm{Ca}$, and NIST 612 standard glass was used to convert normalized ratios to elemental ratios and quantify precision (Kent \& Ungerer 2006, Miller 2007, Jochum et al. 2011). USGS MACS-1 was also measured and provided an estimate of accuracy (see Table S2 in Supplement 1 for measures of accuracy and precision). Bone metal to calcium ratios ( $\mathrm{Me}: \mathrm{Ca}_{i} \mathrm{mg} \mathrm{g}^{-1}$ ) were then averaged across individual humerus bone growth layers to allow for comparison with $\delta^{15} \mathrm{~N}$, size, growth, and age data (see Table S1). Before statistical analyses were performed, data were tested for normality and homogeneity of variances using ShapiroWilk and Levene's tests. In most cases, elemental ratios needed to be log-transformed to meet parametric assumptions. Only $\mathrm{Sr}$ :Ca ratios and $\log (\mathrm{Ba}: \mathrm{Ca})$ displayed distinct ontogenetic changes, resulting in the exclusion of the other trace element data from further analysis.

We used 2 classification systems to determine the age at which an ontogenetic shift occurred. The first considered only the $\delta^{15} \mathrm{~N}$ data while the second considered only the $\mathrm{Sr}: \mathrm{Ca}$ and $\log (\mathrm{Ba}: \mathrm{Ca})$ data. For the first metric, oceanic resource use was first characterized by analyzing the bone $\delta^{15} \mathrm{~N}$ data associated with the age-0 growth layer (first year of life) from all sampled turtles. Based on data indicating that juvenile hawksbills begin to inhabit neritic habitat at SCLs of 20-26 cm in Florida (Meylan \& Redlow 2006) and 23-25 cm throughout the Caribbean (Meylan 1988), we assume that hawksbills in US waters spend at least the first year of their life in the oceanic life stage. Age- $0 \delta^{15} \mathrm{~N}$ data were collected from 23 individuals and ranged between 5.45 and $9.41 \%$ (mean \pm SD: $7.81 \pm 1.25 \%$ ). Given these observations, we used an estimate of $9.5 \%$ as the upper threshold for the hawksbill oceanic life stage. The $\delta^{15} \mathrm{~N}$ chronology of each turtle was then examined, and the first datum that surpassed $9.5 \%$ was assigned the year/age of ontogenetic shift. For the second metric, turtle-specific chronologies of $\mathrm{Sr}$ : Ca ratios and $\log (\mathrm{Ba}: \mathrm{Ca})$ were visually examined to identify the year/age where an abrupt decrease occurred in at least 1 elemental data transect (sensu Ramirez et al. 2019). Ramirez et al. (2019) observed significant declines in these elemental ratios that coincided with increases in $\delta^{15} \mathrm{~N}$ values for Kemp's ridley sea turtles that occupy neritic habitats in the GoM and along the US Atlantic. As the mechanisms underpinning the $\mathrm{Sr}: \mathrm{Ca}$ and $\log (\mathrm{Ba}: \mathrm{Ca})$ patterns remain unknown and are likely linked to individual physiology, this metric relied on consideration of individual turtle data alone rather than population-wide thresholds. Consideration of these additional data allowed for identification of likely ontogenetic shifts in turtles where $\delta^{15} \mathrm{~N}$ data (1) could 
not be collected due to sampling limitations (i.e. when growth layers were too narrow; $\mathrm{n}=2$ ) or (2) were ambiguous (e.g. some Florida turtles where no shift in $\delta^{15} \mathrm{~N}$ was observed; $\mathrm{n}=2$ ). Only turtles with isotopic or elemental data starting at age 0 or $0.75 \mathrm{yr}$ were included in both of these analyses so as not to bias the results.

\subsection{SCL-at-age and somatic growth models}

To estimate ASM, we modeled the relationship between age and SCL using 2 approaches that could accommodate the multiple SCL-at-age data points for individual turtles generated by skeletochronological analysis and yet avoid autocorrelation. First, we used a generalized additive mixed modeling (GAMM) approach to fit a smoothing spline directly to the SCLat-age data (Avens et al. 2015, 2017) that incorporated turtle ID in the model as a random, individual-specific effect. In addition, to allow comparison with prior studies reporting results of parametric growth models such as the von Bertalanffy (VB) growth curve most often applied for sea turtles, we bootstrapped individual annual somatic growth increments to fit Faben's modified VB curve 1000 times and estimate the mean SCL-at-age relationship (Avens et al. 2015, 2017). ASM was estimated using both model fits for comparison and was predicted as the range of ages associated with minimum SCLs reported for nesting females in the region (69.5-78.8 cm) (Carr et al. 1966 [74.9 cm, Costa Rica], Bjorndal et al. $1985[72.4 \mathrm{~cm}$, Costa Rica], Boulon 1994 [78.8 cm, US Virgin Islands], Lagueux et al. $2003[73.5 \mathrm{~cm}$, converted from $70.5 \mathrm{~cm}$ $\mathrm{SCL}_{\min }$, Nicaragua], Beggs et al. 2007 [71.5 cm, converted from $76.2 \mathrm{~cm} \mathrm{CCL}_{\min }$, Barbados], Meylan et al. 2011 [71.8 cm, Puerto Rico], Bellini et al. 2019 [69.5 cm, converted from $74.0 \mathrm{~cm}$ CCL, Brazil]). To evaluate potential regional differences, GAMM splines were also fit separately to the back-calculated SCL-at-age data for turtles stranded in Texas and Florida; however, due to limited sample sizes, it was not possible to fit location-specific VB growth curves for each state.

We then applied a multi-level modeling approach to evaluate the potential influence of different covariates on somatic growth rates. The first model involved a subset of the data comprising only the outermost, 'terminal' growth increment for each turtle, as these were thought to best represent potential foraging habitat near stranding locations, and might therefore offer insight into regional growth patterns.
As this model only incorporated a single growth increment per individual, a mixed modeling approach was not required and instead a simplified generalized additive model (GAM) was used that included stranding state as a proxy for location. Sex-specific growth patterns were modeled using another sub-set of the data obtained from the samples for which sex was determined through necropsy, this time using the GAMM approach to accommodate multiple data points for individual males and females. Similarly, GAMMs were then also applied to the broader dataset to characterize overall associations between growth and SCL, age, and calendar year.

All age and growth analyses were carried out using the statistical software program $\mathrm{R}$ version 3.6.1. (R Core Team 2019). GAMs and GAMMs were implemented using the packages 'mgcv' and 'nlme,' and each incorporated an identity link and robust quasi-likelihood error function (Wood 2006, Pinheiro et al. 2017). Significance of model factors was evaluated using $t$-ratio statistical inference for nonparametric covariates (stranding location, sex) and nonparametric F-ratio tests for continuous covariates (age, SCL, year).

\section{RESULTS}

\subsection{Sample collection}

Humeri were collected from 94 hawksbill sea turtles that stranded along the US coastline (Fig. 1) from 1989 through 2012, ranging in size from 7.5 to $80.8 \mathrm{~cm}$ SCL (mean \pm SD: $33.6 \pm 18.2 \mathrm{~cm}$ ). Stranding locations included northern sites in North Carolina $(\mathrm{n}=2)$ and Georgia $(\mathrm{n}=1)$, but the majority of sampling occurred in Texas $(n=47)$ and Florida (Gulf $n=$ 11; Atlantic $\mathrm{n}=32$ ) (Fig. 2), with 1 turtle for which stranding state was unknown. Of these turtles, 30 were determined to be female, 13 male, and 51 were of unknown sex.

\subsection{Age estimation}

Skeletochronological age estimates at stranding for all turtles spanned 0.25 to $25.75 \mathrm{yr}$ (mean \pm SD: $4.9 \pm$ $5.3 \mathrm{yr}$ ). Back-calculation yielded a total of $451 \mathrm{SCL}$ and age estimate data pairs, with SCL ranging from 4.1 to $80.8 \mathrm{~cm}(34.8 \pm 20.6 \mathrm{~cm})$ and age from 0 to $25.75 \mathrm{yr}(5.7 \pm 5.6 \mathrm{yr})$. Of these data pairs, 172 were associated with females, 53 with males, and 226 with turtles of unknown sex. 


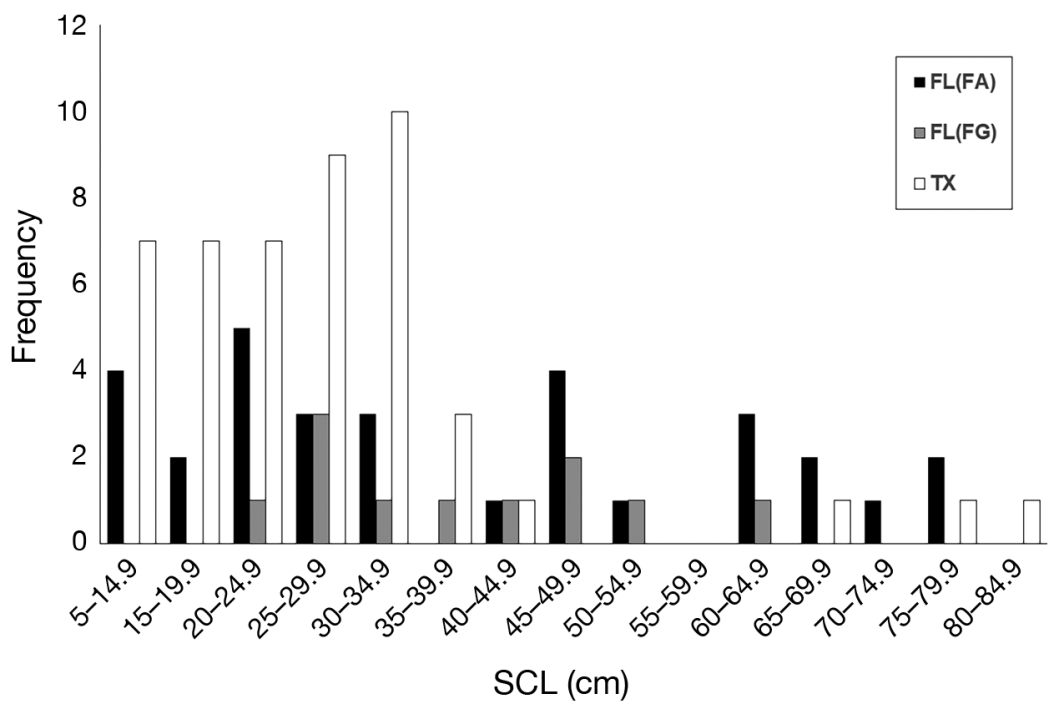

Fig. 2. Size distribution of US-stranded hawksbill sea turtles from which samples were collected relative to straight-line carapace length $\left(\mathrm{SCL}_{i} \mathrm{~cm}\right)$ and stranding state. FL(FA): Florida Atlantic coast; FL(FG): Florida Gulf of Mexico coast; TX: Texas

\subsection{Somatic growth rate calculation}

Back-calculation also yielded 283 annual somatic growth rate increments $\left(\mathrm{cm} \mathrm{SCL} \mathrm{yr}{ }^{-1}\right)$ associated with age estimates of 0 to $24.75 \mathrm{yr}$ (mean \pm SD: $6.0 \pm$ $5.7 \mathrm{yr})$, SCLs from 7.7 to $80.6 \mathrm{~cm}(37.4 \pm 20.6 \mathrm{~cm})$, and calendar years 1987 to $2011(2002 \pm 6)$. Of the growth rates, 115 were from females, 26 from males, and 142 from turtles of unknown sex. Growth rates were binned by $10 \mathrm{~cm}$ SCL size class and compared with other studies for which comparable data were available (Table 1). Size class-specific means and SDs were equivalent to results reported from Florida waters (Wood et al. 2013) and comparable to growth rates measured at a number of other sites throughout the Caribbean (Table 1).

\subsection{Characterizing oceanic to neritic habitat shift}

$\delta^{15} \mathrm{~N}$ data were collected from a total of 153 growth increments in 46 hawksbill humeri (1-7 samples per humerus, mean $=3$ ) from turtles measuring 17.6$68.1 \mathrm{~cm}$ SCL at stranding and ranged from 4.97 to $17.91 \%$. Trace element data were collected from a total of 131 growth increments in 35 humeri from turtles ranging from 22.3 to $68.1 \mathrm{~cm} \mathrm{SCL}$ at stranding. Transition ages could be estimated for 22 turtles, 18 using the $9.5 \% \delta^{15} \mathrm{~N}$ value threshold and 20 using the $\mathrm{Sr}: \mathrm{Ca}$ and $\log (\mathrm{Ba}: \mathrm{Ca})$ elemental profiles. Based on this reduced dataset and the combined interpretation of the 2 ontogenetic shift metrics, the overwhelming majority of hawksbills recruited from oceanic to neritic habitat prior to $2.75 \mathrm{yr}$ of age (Fig. 3, Table 2; see also Fig. S1 in Supplement 2 at www.int-res.com/articles/suppl/n045 p127_supp2.pdf). The total range of estimated transition ages was 0.753.75 yr. Estimates derived from each metric differed slightly, with the $\delta^{15} \mathrm{~N}$ metric suggesting that the majority $(56 \%)$ of juvenile hawksbills transitioned during the $0.75 \mathrm{yr}$ age class and the $\mathrm{Sr}: \mathrm{Ca}$ and $\log (\mathrm{Ba}: \mathrm{Ca})$ metric suggesting the majority $(70 \%)$ of juvenile hawksbills transitioned during the 1.75 yr age class. In most cases, shifts in $\mathrm{Sr}: \mathrm{Ca}$ ratios and $\log (\mathrm{Ba}: \mathrm{Ca})$ coincided with shifts in $\delta^{15} \mathrm{~N}$ values \pm 1 growth increment. For turtles where transition age could be estimated using both metrics ( $\mathrm{n}=16 / 22$ turtles), age estimates matched in 9 turtles $(56 \%)$. In the remaining 7 turtles, age estimates derived using the elemental metric tended to be higher than the $\delta^{15} \mathrm{~N}$ metric $(1 \mathrm{yr}, \mathrm{n}=4 ; 3 \mathrm{yr}, \mathrm{n}=1)$. For turtles with $\delta^{15} \mathrm{~N}$ chronologies that spanned the ontogenetic shift (i.e. 2 sequential growth layers), the mean \pm SD changes in $\delta^{15} \mathrm{~N}$ values before and after the oceanic-to-neritic ontogenetic shift were $1.18 \pm 1.32 \%$ o $(0.12-3.34 ; \mathrm{n}=$ 5) and $2.37 \pm 1.10 \%$ o (0.90-4.02, $\mathrm{n}=8)$ for hawksbills stranded in Florida and Texas, respectively. Mean SCL associated with habitat transition was $22.7 \pm 5.2$ $\mathrm{cm}$ (range $15.7-33.2 \mathrm{~cm}$ ) as predicted by isotope data and $24.4 \pm 4.9 \mathrm{~cm}$ (range $18.8-35.0 \mathrm{~cm}$ ) for trace element data.

\subsection{SCL-at-age and somatic growth models}

The GAMM spline fit to all back-calculated SCLat-age data was significant $\left(\mathrm{p}<0.005\right.$, adjusted $\mathrm{R}^{2}=$ 0.95) and demonstrated non-monotonic growth (Fig. 4A). Random, individual effects in the model were significant (log-likelihood ratio test $\mathrm{p}<0.0001$ ). Region-specific GAMM spline fits were also significant (Texas: $\mathrm{p}<0.001, \mathrm{R}^{2}=0.96$; Florida: $\mathrm{p}<0.001$, $\left.\mathrm{R}^{2}=0.94\right)$, although prediction of SCL at any given age was smaller in Texas than in Florida (Table 3). The bootstrapped Faben's modified VB curve fit yielded a growth coefficient $(k)$ of 0.12 and asymptotic adult length $(L)$ of $81.9 \mathrm{~cm} \mathrm{SCL}$. VB parameters and curve fit from the current study were compara- 


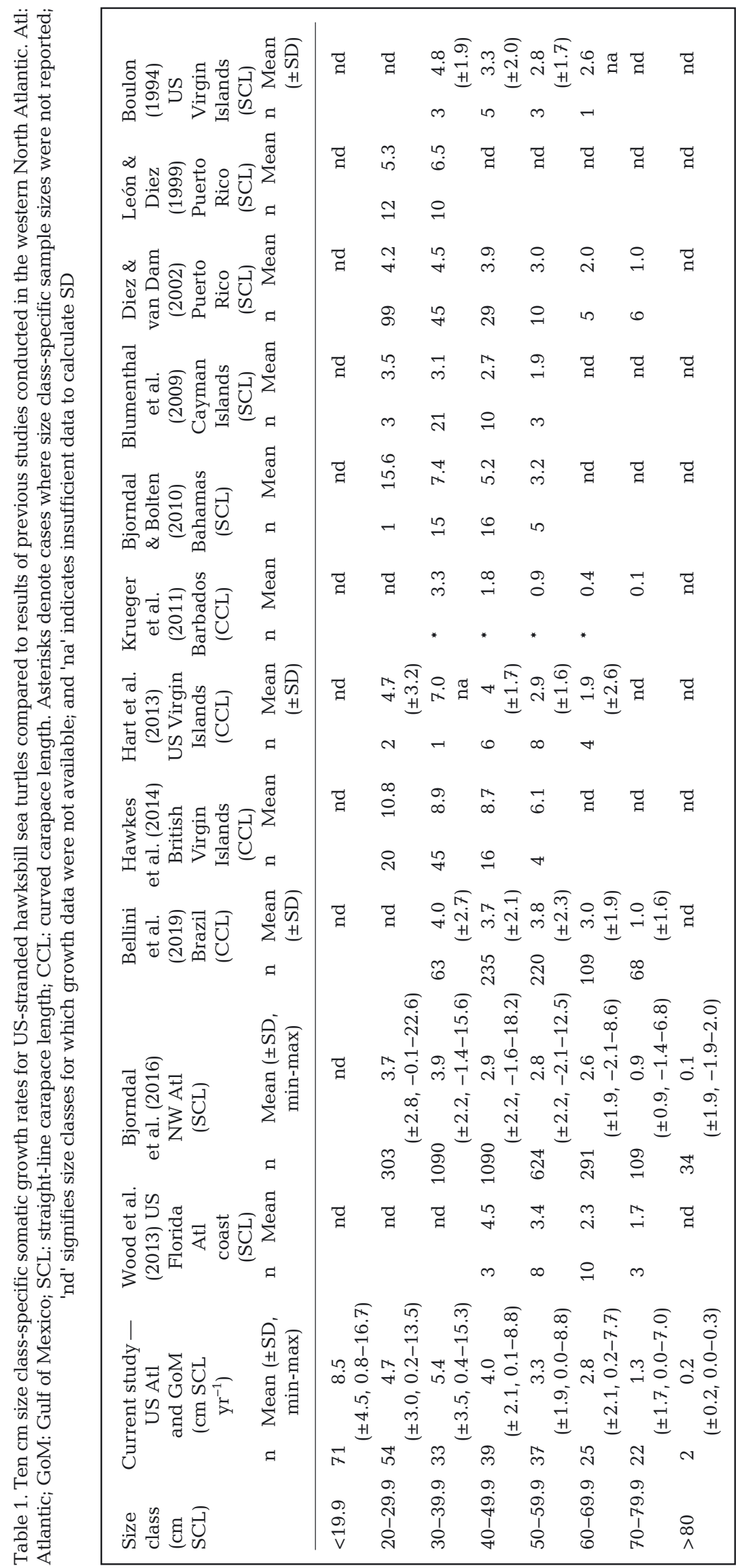

ble to other VB curves fit using mark-recapture data from different Caribbean study sites, as well as the GAMM spline fit also from the current study (Fig. 4B). Lack of larger turtles in the sample for the current study prevented estimation of ASMs corresponding with some larger mean sizes for nesting females reported for potential source populations, which are often >80 cm SCL (Witzell 1983, Diez \& van Dam 2002, Beggs et al. 2007). However, at minimum sizes for mature females reported in the literature, as well as smaller mean sizes (Carr et al. 1966, Witzell 1983, Bjorndal et al. 1985, Boulon 1994, Lagueux et al. 2003, Beggs et al. 2007, Meylan et al. 2011, Bellini et al. 2019), GAMM and VB predictions were similar, indicating that at SCLs ranging from 69.5 to $78.8 \mathrm{~cm}$, ASM estimates range from 15 to $25 \mathrm{yr}$ of age (Table 3 ).

The first somatic growth model incorporated only the final, 'terminal' growth increment for those turtles stranded along the Florida (Atlantic and GoM) and Texas coasts $(\mathrm{n}=71)$; data from individuals stranded in those states where only 1 or 2 samples were recovered (Georgia, North Carolina) were not retained for this first analysis. As the response variable for each predictor variable in GAMs (and by extension GAMMs) is conditioned on other covariates in the model (e.g. SCL, age; Chaloupka \& Limpus 1997), this approach could therefore accommodate differences in stranding size distribution in the 2 regions (Fig. 1). Results of this GAM incorporating stranding location indicated significantly lower somatic growth rates during the year prior to stranding in Texas than in Florida (both GoM and Atlantic coasts) (Fig. 5A, Table 4), reflecting the depressed SCL-at-age GAMM spline fit for Texas relative to Florida (Table 3). For the GAMMs, high levels of concurvity between SCL and age during initial model runs (0.96, with 1.0 representing the worst-case scenario) made it necessary to separate 

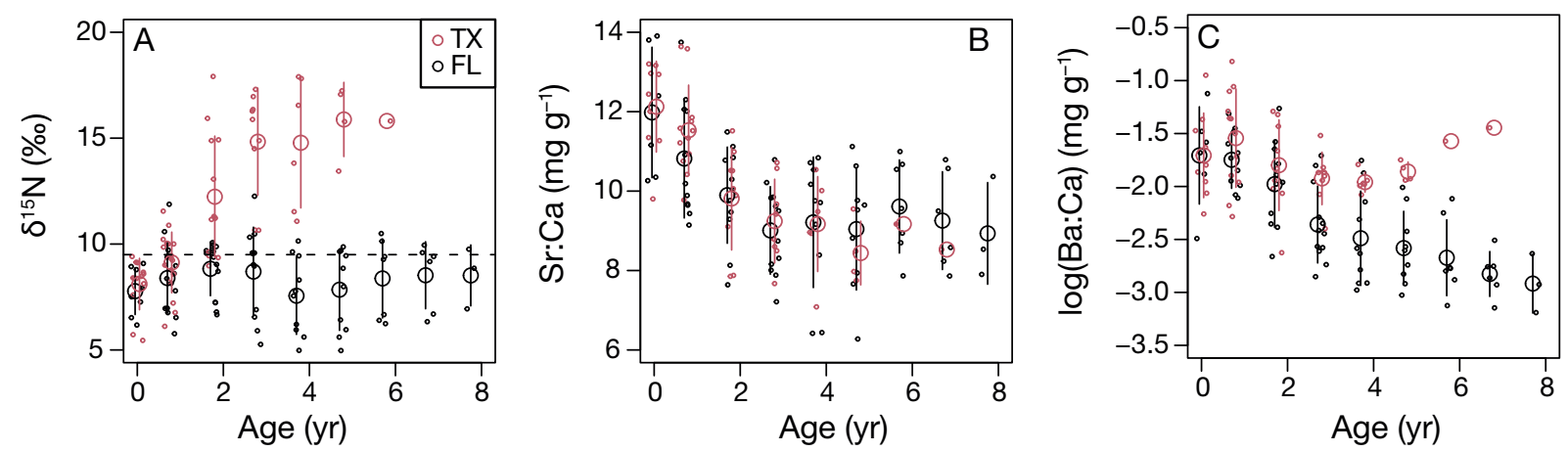

Fig. 3. Mean (large open circles) \pm SD (vertical lines) for (A) $\delta^{15} \mathrm{~N}$, (B) Sr:Ca ratio, and (C) $\log (\mathrm{Ba}$ :Ca) values for hawksbill sea turtles by age and stranding state (TX: Texas; FL: Florida) showing region-specific differences in isotope and elemental signals denoting a shift in habitat use. Data presented (small points) are for all sampled humerus bone growth layers and are jittered to allow for better visualization. In (A), the dashed line denotes $9.5 \%$ o threshold used to identify the timing of an oceanicto-neritic ontogenetic shift. See Section 3.4 for details regarding sample size

Table 2. Age at oceanic-to-neritic habitat shift for juvenile hawksbill sea turtles by parameter estimation method. $\delta^{15} \mathrm{~N}$ used a $\delta^{15} \mathrm{~N}$ threshold of $9.5 \%$ for the oceanic life stage to assess transition from oceanic to neritic habitats. Me:Ca ratio-based transition estimates based on changes in the $\mathrm{Sr}: \mathrm{Ca}$ ratio and $\log (\mathrm{Ba}: \mathrm{Ca})$ ablation transects for each turtle. $\mathrm{n}_{\text {agree }}$ : number of turtles that had similar age at ontogenetic shift estimates for both metrics. Note that this only includes turtles for which age at ontogenetic shift could be estimated for both metrics ( $n=16 / 22$ turtles)

\begin{tabular}{|c|c|c|c|c|c|}
\hline \multirow{2}{*}{$\begin{array}{l}\text { Shift age } \\
\text { (yr) }\end{array}$} & \multirow[b]{2}{*}{$\mathrm{n}$} & \multicolumn{3}{|c|}{ Proportion of turtles (\%) } & \multirow[b]{2}{*}{$\mathrm{n}_{\text {agree }}$} \\
\hline & & $\delta^{15} \mathrm{~N}$ & $\mathrm{n}$ & $\mathrm{Me}: \mathrm{Ca}$ & \\
\hline 0.75 & 10 & 56 & 5 & 25 & 4 \\
\hline 1.75 & 6 & 33 & 14 & 70 & 5 \\
\hline 2.75 & 2 & 11 & - & - & - \\
\hline 3.75 & - & - & 1 & 5 & - \\
\hline
\end{tabular}

these factors into different models (Table 4). For the subset of turtles for which sex was known, GAMM output indicated no significant difference in growth response between males and females $(\mathrm{n}=141$ growth increments, Table 4). However, GAMM output did demonstrate that growth response declined significantly overall with age and size, while no significant association was found with calendar year (n $=283$ growth increments, Fig. 5B,C, Table 4).

\section{DISCUSSION}

Through integration of multiple analytical approaches, we generated the first empirically derived estimates of juvenile hawksbill oceanic stage durations in the western North Atlantic, with turtles transitioning from oceanic to neritic habitats between the ages of $\sim 1$ and $3 \mathrm{yr}$ and SCLs centered around $23-24 \mathrm{~cm}$

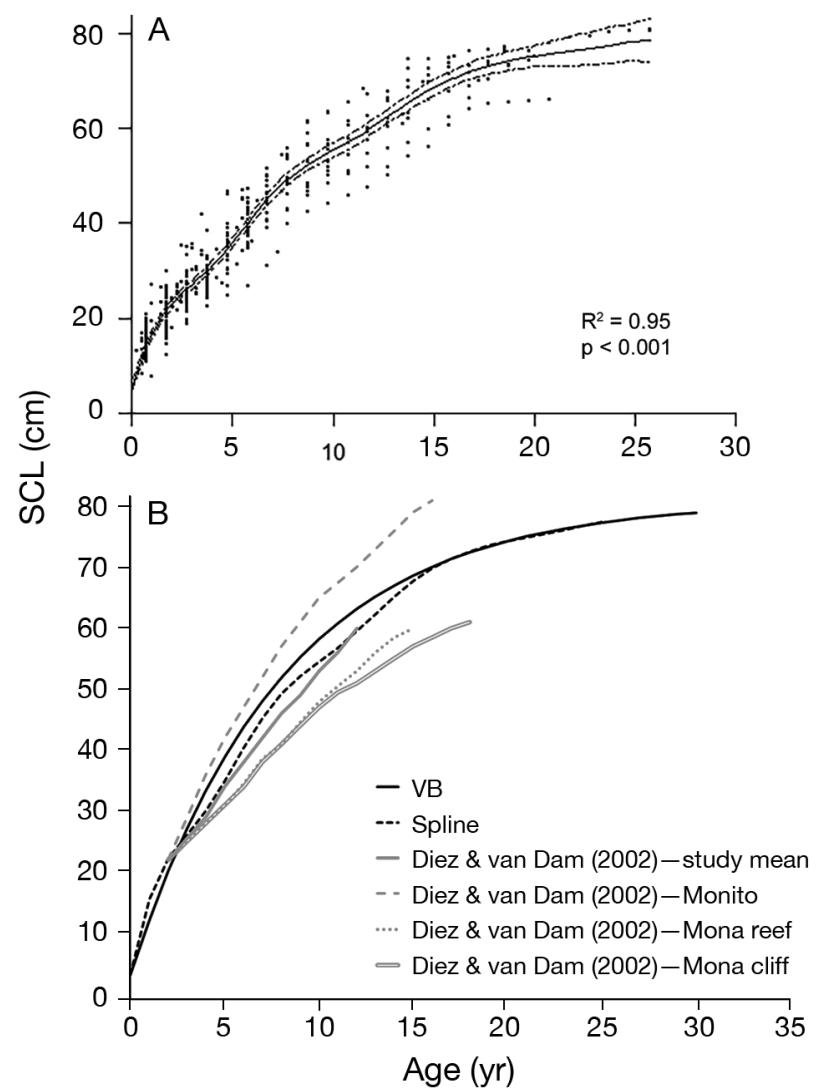

Fig. 4. (A) Generalized additive mixed model (GAMM) smoothing spline fit and 95\% credible interval for straightline carapace length (SCL)-at-age data generated through skeletochronological analysis of US-stranded hawksbill sea turtles. (B) spline fit in (A) (Spline) and bootstrapped Faben's modified von Bertalanffy growth model (VB) with von Bertalanffy growth curves previously published for other hawksbill foraging aggregations in the Caribbean

(range 16-35 cm). Furthermore, despite constraints on the number of samples available for analysis (particularly from adult-sized turtles), these methods also 
Table 3. Mean straight-line carapace lengths $(\mathrm{SCL}, \mathrm{cm})$ for US-stranded hawksbill sea turtles at ages 1 through $25 \mathrm{yr}$, predicted using the generalized additive mixed model (GAMM) smoothing spline (with 95\% credible interval [CI]) and bootstrapped Faben's modified von Bertalanffy growth curve (VB) fit to the skeletochronology SCL-at-age and somatic growth rate data. Sample sizes refer to the number of back-calculated SCL and age estimate data pairs, with $\mathrm{n}=$ 451 for full GAMM and VB models, $\mathrm{n}=213$ for the Floridaonly model, and $n=212$ for the Texas-only model. Dashes represent cells where predicted SCLs exceeded the upper end of the range for samples available for the study. All: combined data from all US stranding locations

\begin{tabular}{|c|c|c|c|c|c|}
\hline \multirow{3}{*}{$\begin{array}{l}\text { Age } \\
\text { (yr) }\end{array}$} & \multicolumn{5}{|c|}{ - Predicted size (cm SCL) } \\
\hline & \multicolumn{2}{|c|}{ Spline - all } & \multirow{2}{*}{$\begin{array}{l}\mathrm{VB} \text { - all } \\
\text { Mean }\end{array}$} & \multicolumn{2}{|c|}{ Spline means } \\
\hline & Mean & $95 \% \mathrm{CI}$ & & Florida & Texas \\
\hline 1 & 16.5 & $16.0-17.0$ & 13.1 & 18.0 & 16.1 \\
\hline 2 & 23.1 & $22.7-23.5$ & 21.1 & 24.0 & 22.6 \\
\hline 3 & 27.1 & $26.7-27.5$ & 28.2 & 27.9 & 26.7 \\
\hline 4 & 31.0 & $30.5-31.5$ & 34.4 & 32.6 & 30.0 \\
\hline 5 & 36.0 & $35.5-36.5$ & 39.9 & 37.7 & 33.4 \\
\hline 6 & 41.3 & $40.7-41.9$ & 44.8 & 42.6 & 36.8 \\
\hline 7 & 46.3 & $45.7-47.0$ & 49.1 & 46.8 & 40.2 \\
\hline 8 & 50.2 & $49.5-50.9$ & 52.9 & 50.4 & 43.6 \\
\hline 9 & 53.1 & $52.4-53.8$ & 56.2 & 53.3 & 46.9 \\
\hline 10 & 55.5 & $54.8-56.3$ & 59.2 & 55.6 & 50.4 \\
\hline 11 & 57.8 & $57.0-58.6$ & 61.9 & 57.7 & 54.1 \\
\hline 12 & 60.5 & $59.0-61.3$ & 64.2 & 59.8 & 57.9 \\
\hline 13 & 63.3 & $62.5-64.1$ & 66.2 & 62.0 & 61.6 \\
\hline 14 & 66.2 & $63.4-67.0$ & 68.1 & 64.4 & 64.9 \\
\hline 15 & 68.7 & $67.8-69.6$ & 69.7 & 67.0 & 67.3 \\
\hline 16 & 70.8 & $70.0-71.6$ & 71.1 & 69.9 & 68.6 \\
\hline 17 & 72.4 & $71.5-73.3$ & 72.3 & 73.1 & 69.3 \\
\hline 18 & 73.6 & $72.6-74.6$ & 73.4 & 76.5 & 69.8 \\
\hline 19 & 74.6 & $73.6-75.6$ & 74.4 & 79.9 & 70.5 \\
\hline 20 & 75.3 & $74.2-76.4$ & 75.3 & - & 71.6 \\
\hline 21 & 75.9 & $75.6-77.3$ & 76.1 & - & 72.8 \\
\hline 22 & 76.5 & $74.9-78.1$ & 76.7 & - & 74.3 \\
\hline 23 & 77.1 & $75.3-78.9$ & 77.3 & - & 75.9 \\
\hline 24 & 77.8 & $75.8-79.8$ & 77.9 & - & 77.4 \\
\hline 25 & 78.4 & $76.4-80.4$ & 78.3 & - & 78.6 \\
\hline
\end{tabular}

made it possible to characterize a span of initial ASM for the study population ranging from 15 to $25 \mathrm{yr}$, addressing a major data gap in supporting assessments for the species in this region. Finally, results of these methods offer novel insight into growth patterns for juvenile hawksbill sea turtles inhabiting US coastal waters, including potential regional differences, and we explore possible underlying causes below.

\subsection{Oceanic stage duration and age at maturation}

Predictions of early SCL-at-age and mean oceanic stage duration generated using different approaches in the current study corresponded with one another, as well as with other available information for the species. Snover et al. (2013) identified the first-year 'annulus' LAG for Hawaiian hawksbills and estimated a mean SCL of $17.5 \mathrm{~cm}$ at the age at which this initial skeletal growth mark is deposited. Similarly, the GAMM spline presented herein, which approximated early size-at-age data more closely than the VB curve, predicted a mean SCL of $16.5 \mathrm{~cm}$ at annulus deposition for US Atlantic hawksbills. Markrecapture efforts have documented that juvenile hawksbills recruit to neritic habitat in the western North Atlantic and Brazil at sizes ranging from 17.6 to $35 \mathrm{~cm}$ SCL (Meylan et al. 2011, Bjorndal et al. 2016, Bellini et al. 2019), and these sizes correspond with approximately 1.5-4 yr of age from GAMM spline and VB curve fits to age and growth data. The means $(23-24 \mathrm{~cm})$ and ranges $(16-35 \mathrm{~cm})$ of SCLs estimated at transition based on the isotopic and elemental data were also comparable to SCLs observed for the smallest juvenile hawksbills in neritic US foraging grounds (Meylan \& Redlow 2006). In addition, isotope and trace element data indicated that virtually all turtles would transition between the ages of $\sim 1$ and $3 \mathrm{yr}$, coinciding with predictions of ages at transition SCLs from our models. Finally, size-at-age estimates based on particle drift models that incorporated swimming behavior for hawksbill hatchlings dispersing from Brazilian beaches to Ascension Island predicted recruitment at around 4.5-5.5 yr of age (Putman et al. 2014). The smallest juveniles at Ascension Island foraging grounds are $33.5 \mathrm{~cm}$ SCL (Weber et al. 2017), which our models predicted to correspond with 4-5 yr of age, coinciding closely with these previous estimates (Putman et al. 2014).

Results presented herein indicate that the relative utility of the isotopic and elemental predictors $\left(\mathrm{Sr}_{\text {, }}\right.$ $\mathrm{Ba}$ ) of habitat transitions varies. For example, although $\delta^{15} \mathrm{~N}$ values have elucidated sea turtle oceanic-to-neritic resource shifts in both the Atlantic and Pacific Oceans (e.g. Avens et al. 2013, Ramirez et al. 2015, 2019, Turner Tomaszewicz et al. 2017), we demonstrate that $\delta^{15} \mathrm{~N}$ values poorly characterize hawksbill recruitment to Florida nearshore habitats where there is a propensity for $\delta^{15} \mathrm{~N}$ values to remain below $10 \%$ throughout the juvenile life stage (Fig. 3A). Other studies have observed similarly low $\delta^{15} \mathrm{~N}$ values in fish and sea turtles that inhabit the oligotrophic West Florida Shelf (e.g. Radabaugh \& Peebles 2014, Vander Zanden et al. 2015), where the cyanobacterium Trichodesmium contributes substantially to primary production (Mulholland et al. 2006, Holl et al. 2007). Through nitrogen fixation, these diazotrophs produce isotopically depleted 


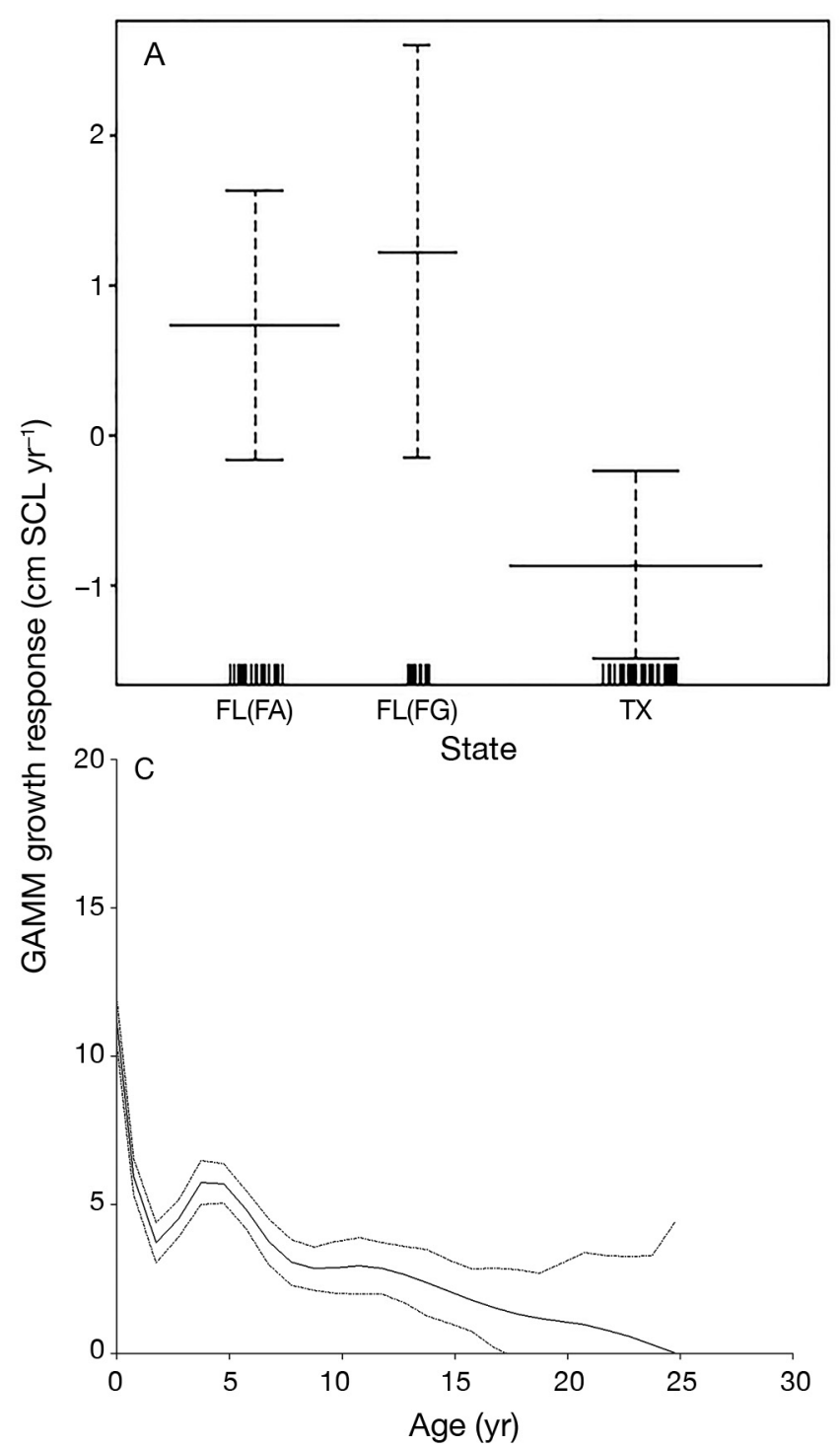

organic matter that depresses baseline $\delta^{15} \mathrm{~N}$ values relative to the average marine habitat (Montoya 2007). In contrast, diazotrophs are less common in coastal Texas habitats, yielding higher baseline $\delta^{15} \mathrm{~N}$ values (Holl et al. 2007). Interestingly, post-transition $\delta^{15} \mathrm{~N}$ values for hawksbills in Texas are higher than would be expected for a $\delta^{15} \mathrm{~N}$ baseline difference alone. This observation, combined with the divergence in region-specific $\log (\mathrm{Ba}: \mathrm{Ca})$ values following the oceanic-to-neritic ontogenetic shift (i.e. $>2$ yr old; Fig. 3C), may indicate differences in trophic ecology, environmental barium source, or both between hawksbill turtles that inhabit Florida vs. Texas waters. Hawksbills are generally considered sponge specialists, but little is known about their diet in Texas. If Texas hawksbills are generalist bottom feeders like Kemp's ridleys in the same region, which

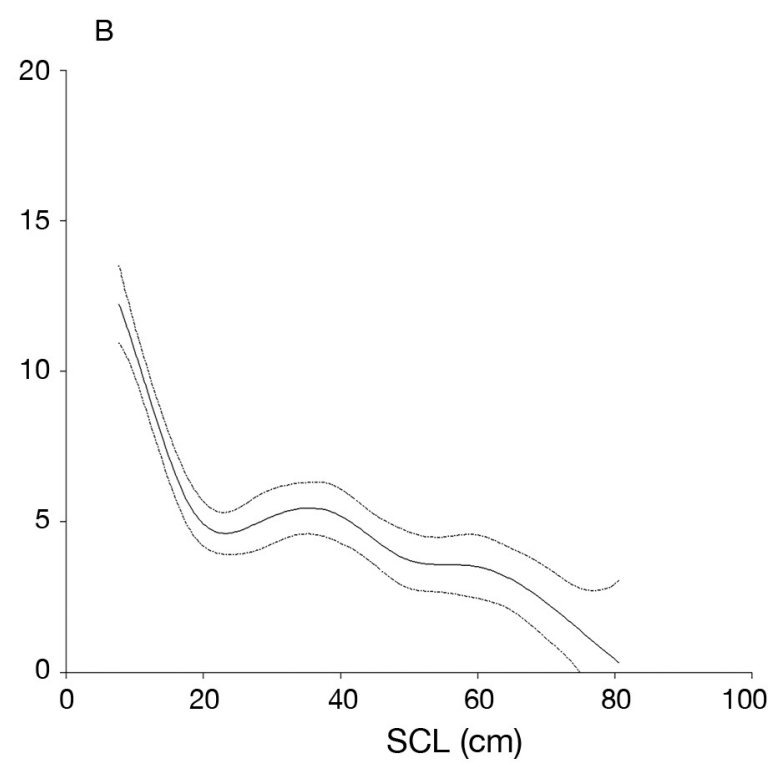

Fig. 5. Generalized additive mixed model (GAMM) output representing relationships between somatic growth response and (A) stranding state with CI [FL(FA): Florida Atlantic coast; FL(FG): Florida Gulf of Mexico coast; TX: Texas], (B) straight-line carapace length (SCL, cm) as measured from the nuchal notch to the longest posterior tip (SCL-tip [cm]), and (C) age (yr). The short, vertical lines in (A) ('rugs') above the $x$-axis represent the number and distributions of covariate values. In (B) and (C) solid lines denote mean spline fit, and dashed lines correspond with $95 \%$ credible bands

forage on a variety of benthic invertebrate prey (i.e. higher $\delta^{15} \mathrm{~N}$ values), they may also consume higher levels of sediment (and thereby baryte) that would lead to elevated Ba:Ca ratios (Peek \& Clementz 2012). Additional research is ultimately needed to clarify mechanisms underpinning variability in sea turtle bone elemental ratios. Nevertheless, our results suggest $\log (\mathrm{Ba}: \mathrm{Ca})$ provides a more reliable metric than $\delta^{15} \mathrm{~N}$ values to evaluate ontogenetic shifts for sea turtles that recruit to Florida.

Furthermore, our predictions of 15-25 yr ASM at smaller nesting female SCLs of $69.5-78.8 \mathrm{~cm}$ also agree with data previously reported for hawksbills in the Caribbean. Most notably, VB growth curves fit to extensive juvenile mark-recapture data from Puerto Rico yielded an estimated mean of 14.7 yr to grow from size at neritic recruitment $(20-30 \mathrm{~cm}$ SCL) to 
Table 4. Summary statistics for generalized additive mixed model (GAMM) fits to US-stranded hawksbill sea turtle somatic growth rate data back-calculated using skeletochronology to evaluate potential influence of size, age, sex, and stranding location on growth response. SCL: straight-line carapace length; AIC: Akaike's information criterion; edf: estimated degrees of freedom; FL(FG): Florida Gulf of Mexico coast; TX: Texas. Dashes denote absence of results for models that only included continuous covariates. Significant results $(\mathrm{p}<0.05)$ are highlighted in bold

\begin{tabular}{|c|c|c|c|c|c|c|c|c|c|c|c|c|}
\hline \multirow{2}{*}{ Model } & \multirow{2}{*}{$\mathrm{n}$} & \multirow{2}{*}{$\begin{array}{l}\text { Adjusted } \\
\mathrm{r}^{2}\end{array}$} & \multirow{2}{*}{ AIC } & \multicolumn{4}{|c|}{ Smooth terms } & \multicolumn{4}{|c|}{ Parametric coefficients } & \multirow[b]{2}{*}{$\operatorname{Pr}>\mid t$} \\
\hline & & & & Variable & Edf & $F$ & $\operatorname{Prob}(F)$ & Variable & Estimate & $\mathrm{SE}$ & $t$ & \\
\hline \multirow{2}{*}{$\begin{array}{l}\text { Growth SCL+ } \\
\text { State }\end{array}$} & \multirow[t]{2}{*}{$71^{\mathrm{a}}$} & \multirow[t]{2}{*}{0.39} & \multirow[t]{2}{*}{341} & \multirow[t]{2}{*}{ SCL } & \multirow[t]{2}{*}{5} & \multirow[t]{2}{*}{8} & \multirow[t]{2}{*}{$<0.001$} & $\mathrm{FL}(\mathrm{FG})$ & 0.5 & 0.96 & 0.56 & 0.58 \\
\hline & & & & & & & & TX & -1.6 & 0.78 & -2 & 0.05 \\
\hline \multirow{2}{*}{$\begin{array}{l}\text { Growth Age+ } \\
\text { State }\end{array}$} & \multirow[t]{2}{*}{$71^{\mathrm{a}}$} & \multirow[t]{2}{*}{0.34} & \multirow[t]{2}{*}{344} & \multirow[t]{2}{*}{ Age } & \multirow[t]{2}{*}{1} & \multirow[t]{2}{*}{23} & \multirow[t]{2}{*}{$<0.001$} & $\mathrm{FL}(\mathrm{FG})$ & 6.1 & 0.98 & 0.73 & 0.47 \\
\hline & & & & & & & & TX & -1.0 & 0.73 & -1.38 & 0.17 \\
\hline \multirow{2}{*}{$\begin{array}{l}\text { Growth SCL + } \\
\text { Year + Sex }\end{array}$} & \multirow[t]{2}{*}{$141^{\mathrm{b}}$} & \multirow[t]{2}{*}{0.60} & \multirow[t]{2}{*}{715} & SCL & 4 & 21 & $<0.001$ & \multirow[t]{2}{*}{ Sex } & \multirow[t]{2}{*}{0.6} & \multirow[t]{2}{*}{0.67} & \multirow[t]{2}{*}{1} & \multirow[t]{2}{*}{0.35} \\
\hline & & & & Year & 1 & 1 & 0.45 & & & & & \\
\hline \multirow{2}{*}{$\begin{array}{l}\text { Growth Age + } \\
\text { Year + Sex }\end{array}$} & \multirow[t]{2}{*}{$141^{\mathrm{b}}$} & \multirow[t]{2}{*}{0.60} & 722 & Age & 8 & 20 & $<0.001$ & Sex & 0.6 & 0.67 & 0.94 & 0.35 \\
\hline & & & & Year & 1 & 0 & 0.88 & & & & & \\
\hline Growth SCL + & $283^{b}$ & 0.47 & 1418 & SCL & 6 & 33 & $<0.001$ & - & - & - & - & - \\
\hline Year & & & & Year & 1 & 1 & 0.77 & & & & & \\
\hline Growth SCL & $283^{b}$ & 0.47 & 1414 & SCL & 6 & 33 & $<0.001$ & - & - & - & - & - \\
\hline Growth Age + & $283^{b}$ & 0.57 & 1392 & Age & 8 & 45 & $<0.001$ & - & - & - & - & - \\
\hline Year & & & & Year & 1 & 0 & 0.90 & & & & & \\
\hline Growth Age & $283^{\mathrm{b}}$ & 0.57 & 1388 & Age & 8 & 45 & $<0.001$ & - & - & - & - & - \\
\hline
\end{tabular}

sizes associated with maturity (Diez \& van Dam 2002). Interestingly, the mean size of $23 \mathrm{~cm}$ SCL at the start of these VB curves for several Puerto Rico study sites (Diez \& van Dam 2002) corresponds with approximately 2 yr of age according to our models. Considering this adjustment and shifting the Puerto Rico hawksbill mean SCL-at-age VB model fit accordingly results in a curve that integrates remarkably well with predictions from models in the current study (Fig. 4B). Similarly, extrapolation of markrecapture data from Yucatan waters has resulted in predictions of $14 \mathrm{yr}$ ASM at minimum nesting sizes of $80 \mathrm{~cm}$ SCL and $24 \mathrm{yr}$ at $90 \mathrm{~cm}$ SCL (GarduñoAndrade et al. 1999). Genetic inference has also been used to estimate generation times for nesting females in Antigua, and results are comparable to results of the current study, with ASM predictions of 14-24 yr $($ mean $=19$ yr) $($ Levasseur et al. 2020). Finally, other lines of correspondence stem from compilation of long-term re-sighting records reported from myriad tag and recapture locations for western North Atlantic hawksbill aggregations. For example:

(1) Ordoñez Espinosa et al. (2010) presented data for a $26.1 \mathrm{~cm}$ SCL juvenile hawksbill tagged in Puerto Rico that was observed nesting in Panama $15 \mathrm{yr}$ later. Added to our estimate of 2-3 yr at initial size, this would result in an estimated age at nesting of 17-18 yr.

(2) Moncada et al. (2020) described a $40.7 \mathrm{~cm}$ SCL juvenile tagged in Cuba that was observed nesting in
Barbados at $85.8 \mathrm{~cm}$ SCL after an interval of $\sim 13.6 \mathrm{yr}$. Given that our models predict $\sim 6 \mathrm{yr}$ of age at initial size, this would result in an age estimate of 19-20 yr at nesting.

(3) Bjorndal et al. (2008) reported a maximum interval of $9.4 \mathrm{yr}$ to grow from $45.1 \mathrm{~cm}$ SCL to maturation for a juvenile tagged in the Bahamas and later observed nesting in Tobago. Our estimate of 6-7 yr of age at the initial size of $45.1 \mathrm{~cm}$ SCL would yield an age estimate at nesting for this turtle of 15.4$16.4 \mathrm{yr}$.

Looking outside the Caribbean, our SCL-at-age and ASM predictions were also consistent with results of studies conducted in the South Atlantic. At a foraging ground in Brazil, models of markrecapture somatic growth data estimated that a mean of $13 \mathrm{yr}$ would be required for hawksbills to grow from $28.4 \mathrm{~cm}$ CCL at recruitment to $74 \mathrm{~cm}$ CCL minimum nesting female size (Bellini et al. 2019). Adding this estimate to recruitment ages of 3-4 yr predicted by our models (after converting size at recruitment to SCL as per Bjorndal et al. 2016) yields an initial ASM estimate for this population of 16-17 yr. This prediction is also supported by re-sightings of larger tagged juveniles from another Brazilian study site that were later reported nesting after intervals of 8.9-18.0 yr (Santos et al. 2019). Initial sizes of these juveniles ranged from 51.7 to $60.1 \mathrm{~cm}$ SCL (converted from CCL as per Bjorndal et al. 2016) and were predicted to correspond with mean ages of 8-13 yr according to 
our models, which would result in estimates of age at nesting for these individuals of 18-31 yr. Although somewhat higher than our ASM estimates, it should be noted that these turtles were not known to be first-time nesters at re-sighting and therefore time intervals reported for these turtles represent maximum ASM. Finally, based on mean growth rates of hawksbills ranging from 38 to $69 \mathrm{~cm}$ CCL at a foraging site near Ascension Island, Weber et al. (2017) estimated that it would take resident juvenile hawksbills $16-17$ yr to grow to adult size. Adding this stage duration estimate to ages of 4-5 yr at recruitment predicted by our growth models (above) and results of particle drift modeling (Putman et al. 2014) yields ASM estimates of 20-22 yr for this population.

In the Pacific, growth models based on skeletochronology data from Hawaiian hawksbills that assumed maturation at $78.6 \mathrm{~cm}$ SCL yielded mean ASM predictions of 17-22 yr, similar to Atlantic estimates in the current study, but the total possible range of estimates was very broad, from 11 to $38 \mathrm{yr}$ (Snover et al. 2013). However, these results contrast sharply with data from mark-recapture studies in the South Pacific, where mean ASM predictions for hawksbills in Australian waters range from $~ 30$ to 40 yr (Limpus \& Miller 2008, Bell and Pike 2012). Delayed maturation in this region is thought to perhaps relate to longer oceanic stage durations, as juveniles undertake the neritic shift at much larger sizes in Australia than in the Caribbean and exhibit much slower subsequent neritic growth (Bell \& Pike 2012, NMFS \& USFWS 2013).

While the broad agreement between our results and those of many other studies is encouraging, we recognize that our analyses were impeded by lower representation from larger turtles $>80 \mathrm{~cm}$ SCL more typical of mean nesting female size, limiting inference regarding the total range of possible ASMs. Size at sexual maturation (SSM) within sea turtle populations can vary widely both within and between the sexes, including possibly for hawksbills (Meylan et al. 2011), which can in turn correspond with a broad scope for ASM as well (Avens et al. 2015, 2017, 2020a). In reptiles and amphibians, maturation is associated with an abrupt decrease in somatic growth, which corresponds with a significant decrease in LAG spacing, termed 'rapprochement' (reviewed by Avens et al. 2015). LAG compaction consistent with rapprochement has been identified in adult female and male loggerhead, Kemp's ridley, and leatherback Dermochelys coriacea sea turtles, allowing estimation of ASM and SSM as the ages and SCLs associated with rapprochement LAGs, as well as post-maturation longevity from LAG counts following rapprochement (Avens et al. 2015, 2017, 2020a). Encouragingly, Kawazu et al. (2015) documented a significant reduction in somatic growth associated with maturation in captive hawksbills, which should manifest as a significant decrease in LAG spacing, given the interrelatedness of SCL and HSD (Avens et al. 2012, 2015, 2017, this study). Unfortunately, lack of samples from larger turtles in the current study did not allow for comprehensive analysis of rapprochement-related characteristics, and as a result, our estimates of initial ASM (15$25 \mathrm{yr}$ ) may be skewed lower than the true range of total possible ASMs for the population as a whole. As a result, future hawksbill skeletochronology studies would benefit from increased representation of large juvenile and adult life stages, to expand the predictive scope of age and growth models, as well as to enhance understanding of sex-specific maturationrelated attributes.

\subsection{Somatic growth}

The geographic extent of the current study falls toward the margin of the circumtropical range typically expected for hawksbill sea turtles. However, growth data for hawksbills in US coastal waters reported in this study are consistent with those from numerous sites in the Caribbean and Brazil and agree with available data from mark-recapture studies in Florida waters (Wood et al. 2013, Gorham et al. 2014). Size class-specific means for small juveniles from a few Caribbean locations were higher than those we calculated for comparably sized juveniles in US waters; nevertheless, for each juvenile size class, the total range of our growth rates either approached or encompassed the measured and extrapolated annual rates reported for other Atlantic Ocean basin studies (Table 1). Furthermore, the skeletochronology growth data for hawksbills $>80 \mathrm{~cm}$ SCL in the current study were low and comparable to those reported from a compilation of adult hawksbill markrecapture growth data $\left(\right.$ mean $=0.3 \mathrm{~cm} \mathrm{CCL} \mathrm{yr}^{-1}$, Omeyer et al. 2017). Taken together, these comparisons suggest that at least a portion of hawksbills resident in US waters are occupying suitable habitat containing resources necessary for foraging and growth, albeit at the northern extent of their range (Wood et al. 2013, Gorham et al. 2014). In fact, analogous distribution can be seen in Brazil where hawksbills exhibit residency at southern latitudes comparable to those of Texas and Florida in the northern 
hemisphere, even though winter water temperatures can be as cold as $13^{\circ} \mathrm{C}$ (Proietti et al. 2012).

Although sample size for the current study was somewhat constrained, results of modeling approaches indicated a significant influence of several factors on somatic growth response for US-stranded hawksbills. First, we found a non-monotonic growth pattern with significant association between growth and both SCL and age, similar to that demonstrated for Caribbean populations (Diez \& van Dam 2002, Krueger et al. 2011, Bjorndal et al. 2016). While monotonic growth for hawksbills has been proposed in a few studies in the Atlantic and Pacific (e.g. Mortimer et al. 2003, Bell \& Pike 2012, Wood et al. 2013, Bellini et al. 2019), these findings may reflect the absence of available data from the smallest juveniles that would allow characterization of early growth. For example, in the current study, early-stage juveniles $<20 \mathrm{~cm}$ SCL exhibited a high initial growth response as is typical for sea turtles, which then appeared to decrease to a low point at the mean SCLs $(23-24 \mathrm{~cm})$ and ages $(\sim 1-3 \mathrm{yr})$ associated with the oceanic-to-neritic habitat shift. This slowing of somatic growth at transition is consistent with the initial low growth rates observed for the smallest-sized neritic hawksbills (20-30 cm SCL) in other studies (León \& Diez 1999, Diez \& van Dam 2002, Blumenthal et al. 2009, Hart et al. 2013). Subsequent to recruitment, US juvenile hawksbill growth response exhibited a potential secondary peak, persisting until approximately $35 \mathrm{~cm} \mathrm{SCL}$ and $5 \mathrm{yr}$ of age before decreasing progressively through maturation. A similar transient increase in somatic growth rates for mid-sized (30-40 cm SCL) juvenile hawksbills has been demonstrated at other study sites in the Caribbean (Krueger et al. 2011, Hart et al. 2013, Bjorndal et al. 2016) and in the eastern Pacific Ocean (Llamas et al. 2017). Yet while elevated growth response subsequent to neritic recruitment occurs in the Indian and western South Pacific Oceans as well, it appears to be delayed until $50-60 \mathrm{~cm}$, or even $60-70 \mathrm{~cm} \mathrm{CCL}$, perhaps due to larger size at neritic transition for these populations (Mortimer et al. 2003, Bell \& Pike 2012). Augmented growth response in mid-sized neritic juveniles could result from ontogenetic changes in foraging behavior, as it has been proposed that initial neritic recruits forage on more diverse items and/or require a period of physiological adjustment before shifting to spongivory, potentially resulting in sub-optimal nutritional intake (Bjorndal \& Bolten 2010). However, as turtles establish and refine neritic resource use, this could result in optimization of forage selectivity, which in turn might manifest as a sec- ondary peak in growth (Bjorndal \& Bolten 2010, Krueger et al. 2011).

A significant regional difference in growth response was also observed for US hawksbills, with markedly lower growth rates and SCL-at-age predictions in Texas relative to Florida (both GoM and Atlantic coasts). While the size distributions from the 2 areas did differ somewhat, model results condition covariate response relative to one another, accommodating such differences. Furthermore, the SCL-atage curves for the 2 areas diverge. Variability in hawksbill growth has also been described in prior studies across a broad scope of spatial scales. For example, even among relatively closely spaced foraging sites in Puerto Rico, growth trajectories diverged substantially (Diez \& van Dam 2002). On an intermediate level, despite overall high growth rates in the Caribbean, Krueger et al. (2011) found surprisingly slow annual growth rates in juveniles inhabiting foraging locations near Barbados, more similar to data reported from Australia (Limpus \& Miller 2008, Bell \& Pike 2012). Extensive inter- and intra-population variability in somatic growth has been demonstrated for numerous marine organisms, including other cheloniid sea turtles (Avens et al. 2012, 2013, $2015,2017,2020 b$ ), with proposed underlying mechanisms including movement energetics, behavior, habitat quality, density dependence, and trophic ecology, among others (Blanck \& Lamouroux 2007). The spatial extent of movements needed to acquire sufficient nutrition can relate to habitat and forage type, availability, and/or quality, potentially resulting in site-specific differences in energetic trade-offs between movements and somatic growth (Dmitriew 2011). Tracking data suggest that hawksbill home range sizes and transit distances between foraging areas and resting sites may differ among foraging locations (e.g. van Dam \& Diez 1998, Blumenthal et al. 2009, Scales et al. 2011, Berube et al. 2012, Hart et al. 2012, Wood et al. 2017, Selby et al. 2019). However, similar somatic growth and body condition have been reported for both hawksbills occupying more typical hard-bottom foraging sites and those in seagrass habitat thought to perhaps be less optimal (Bjorndal \& Bolten 2010). In another Caribbean hawksbill study site comprising solely hard-bottom habitat, no correspondence was demonstrated between density of preferred forage items and somatic growth, but a decrease in growth response was observed coincident with increased turtle abundance, suggesting potential density-dependent effects (Krueger et al. 2011). In contrast, positive correspondence between turtle density and somatic growth 
was found at other hard-bottom sites, but in the absence of information regarding habitat carrying capacity, differences in growth rates have been attributed to variability in food availability (Diez \& van Dam 2002). Furthermore, given the relatively low population levels of hawksbill sea turtles in the Caribbean due to long-term over-exploitation, density-dependent effects are not thought to significantly influence somatic growth response overall (Bjorndal et al. 2016). As a result, further investigation into the habitat use and foraging ecology of hawksbills inhabiting Texas waters is needed to better understand the factors underlying regional differences in US hawksbill growth patterns, as well as implications for relative time to maturation and eventual contribution to source reproductive populations.

In contrast to the significant model covariates, we observed no difference in growth response between males and females for the known-sex subset of the sample population. These results are consistent with reports from the few other Caribbean hawksbill foraging populations for which sex-specific juvenile somatic growth data are available (Krueger et al. 2011, Hart et al. 2013), as well as for 1 site in the northern portion of the Australian Great Barrier Reef (Bell \& Pike 2012). However, an earlier study in the southern portion of the reef produced a contrasting result, demonstrating faster somatic growth for juvenile female hawksbills (Chaloupka \& Limpus 1997), and the reasons for the discrepancy remain unclear. Similarly, sex-specific differences in growth rates were not found for juvenile loggerhead sea turtles in the western North Atlantic (Avens et al. 2013), yet subadult males did begin to exhibit significantly greater growth response than females (Avens et al. 2015). As a result, in addition to benefitting characterization of ASM and SSM as mentioned above, increased skeletochronological data collection from adult hawksbills might offer better insight into potential late-stage, sex-specific differences in somatic growth.

Finally, whereas previous analyses of hawksbill growth rates in the western Atlantic have yielded significant temporal trends (Krueger et al. 2011, Bjorndal et al. 2016, Bellini et al. 2019), results of the current study indicated a lack of correspondence between growth response and calendar year. Most notably, results of models incorporating compiled regional growth data collected from 1980 through 2013 primarily in the Caribbean, but also including sites along the Florida Atlantic, western Yucatán Peninsula in Mexico, and Brazilian coasts, demonstrated a long-term, significant decline in growth from 1997 through the end of the study period in
2013 (Bjorndal et al. 2016). Given that our study overlapped somewhat in spatial and temporal scope with the previous integrated analyses and involved comparable size classes, this disparity was unexpected, yet observed differences might have resulted from the smaller sample sizes and incorporation of a novel study site (Texas) in the current study. Nonetheless, the potential for smaller-scale differences in somatic growth trends to occur in response to local factors would perhaps be relevant for spatially targeted management and conservation efforts and as such is of interest for future study.

Acknowledgements. We greatly appreciate all of the efforts made by the National Sea Turtle Stranding and Salvage Network (STSSN) to collect the samples that made this study possible, with special thanks to participants in Florida and Texas, in particular to A.F. Amos, A. Foley, and P. Plotkin. Thanks also to N. Bacheler, A. Chester, H. Frandsen, C. Gredzens, B. Stacy, J. Shelby Walker, and 2 anonymous reviewers whose insightful comments were integral to improving this manuscript. Research was authorized by USFWS ESA permit number TE-676379-5 issued to the National Marine Fisheries Service's Southeast Fisheries Science Center.

\section{LITERATURE CITED}

Amos AF (1989) The occurrence of hawksbills (Eretmochelys imbricata) along the Texas coast. In: Eckert SA, Eckert KL, Richardson TH (compilers) Proceedings of the Ninth Annual Workshop on Sea Turtle Conservation and Biology. NOAA Tech Memo NMFS-SEFSC-232, p 9-11

Avens L, Snover ML (2013) Age and age estimation in sea turtles. In: Wyneken J, Lohmann KJ, Musick JA (eds) The biology of sea turtles. CRC Press, Boca Raton, FL, p 97-134

Avens L, Goshe LR, Harms CA, Anderson ET and others (2012) Population characteristics, age structure, and growth dynamics of neritic juvenile green turtles in the northeastern Gulf of Mexico. Mar Ecol Prog Ser 458: 213-229

Avens L, Goshe LR, Pajuelo M, Bjorndal KA and others (2013) Complementary skeletochronology and stable isotope analyses offer new insight into juvenile loggerhead sea turtle oceanic stage duration and growth dynamics. Mar Ecol Prog Ser 491:235-251

Avens L, Goshe LR, Coggins L, Snover ML, Pajuelo M, Bjorndal KA, Bolten AB (2015) Age and size at maturation and adult-stage duration for loggerhead sea turtles in the western North Atlantic. Mar Biol 162:1749-1767

Avens L, Goshe LR, Coggins L, Shaver DJ, Higgins B, Landry AM, Bailey R (2017) Variability in age and size at maturation, reproductive longevity, and long-term growth dynamics for Kemp's ridley sea turtles in the Gulf of Mexico. PLOS ONE 12:e0173999

Avens L, Goshe LR, Zug GR, Balazs GH, Benson SR, Haris H (2020a) Regional comparison of leatherback sea turtle maturation attributes and reproductive longevity. Mar Biol 167:4 
Avens L, Ramirez MD, Hall AG, Snover ML and others (2020b) Regional differences in Kemp's ridley sea turtle growth trajectories and expected age at maturation. Mar Ecol Prog Ser 654:143-161

Bean SB, Logan JM (2019) Stable isotope analyses of coldstunned Kemp's ridley (Lepidochelys kempii) sea turtles at the northern extent of their coastal range. Mar Biol 166:64

* Beggs JA, Horrocks JA, Krueger BH (2007) Increase in hawksbill sea turtle Eretmochelys imbricata nesting in Barbados, West Indies. Endang Species Res 3:159-168

Bell I, Pike DA (2012) Somatic growth rates of hawksbill turtles Eretmochelys imbricata in a northern Great Barrier Reef foraging area. Mar Ecol Prog Ser 446:275-283

Bellini C, Santos AJB, Patrício AR, Bortolon LFW and others (2019) Distribution and growth rates of immature hawksbill turtles Eretmochelys imbricata in Fernando de Noronha, Brazil. Endang Species Res 40:41-52

*Berube MD, Dunbar SG, Rützler K, Hayes WK (2012) Home range and foraging ecology of juvenile hawksbill sea turtles (Eretmochelys imbricata) on inshore reefs of Honduras. Chelonian Conserv Biol 11:33-43

Bjorndal KA, Bolten AB (2010) Hawksbill sea turtles in seagrass pastures: success in a peripheral habitat. Mar Biol 157:135-145

Bjorndal KA, Carr A, Meylan AB, Mortimer JA (1985) Reproductive biology of the hawksbill Eretmochelyls imbricata at Tortuguero, Costa Rica, with notes on the ecology of the species in the Caribbean. Biol Conserv 34:353-368

Bjorndal KA, Clovis T, Reich KJ, Alkins G, Eliazar PJ, Bolten AB (2008) Juvenile hawksbill tagged in the Bahamas nests in Tobago. Mar Turtle Newsl 122:10-11

* Bjorndal KA, Chaloupka M, Saba VS, Diez CE and others (2016) Somatic growth dynamics of West Atlantic hawksbill sea turtles: a spatio-temporal perspective. Ecosphere $7: \mathrm{e} 01279$

Blanck A, Lamouroux N (2007) Large-scale intraspecific variation in life-history traits of European freshwater fish. J Biogeogr 34:862-875

* Blumenthal JM, Austin TJ, Bell CDL, Bothwell JB and others (2009) Ecology of hawksbill turtles, Eretmochelys imbricata, on a western Caribbean foraging ground. Chelonian Conserv Biol 8:1-10

Boulon RH Jr (1994) Growth rates of wild juvenile hawksbill turtles, Eretmochelys imbricata, in St. Thomas, United States, Virgin Islands. Copeia 1994:811-814 doi: 10. 2307/1447200

Bowen BW, Grant WS, Hillis-Starr Z, Shaver DJ, Bjorndal KA, Bolten AB, Bass AL (2007) Mixed-stock analysis reveals the migrations of juvenile hawksbill turtles (Eretmochelys imbricata) in the Caribbean Sea. Mol Ecol 16:49-60

Carr A (1987) New perspectives on the pelagic stage of sea turtle development. Conserv Biol 1:103-121

Carr A, Hirth H, Ogren L (1966) The ecology and migrations of sea turtles. 6. The hawksbill turtle in the Caribbean Sea. Am Mus Novit 2248:1-29

Ceriani SA, Roth JD, Sasso CR, McClellan CM and others (2014) Modeling and mapping isotopic patterns in the Northwest Atlantic derived from loggerhead sea turtles. Ecosphere 5:122

Chaloupka M, Limpus CJ (1997) Robust statistical modelling of hawksbill sea-turtle growth rates (southern Great Barrier Reef). Mar Ecol Prog Ser 146:1-8

Crouse DT (1999) Population modeling and implications for
Caribbean hawksbill sea turtle management. Chelonian Conserv Biol 3:185-188

*Diez CE, van Dam RP (2002) Habitat effect on hawksbill turtle growth rates on feeding grounds at Mona and Monito Islands, Puerto Rico. Mar Ecol Prog Ser 234: 301-309

Dmitriew CM (2011) The evolution of growth trajectories: What limits growth rate? Biol Rev Camb Philos Soc 86: 97-116

Eaton C, McMichael E, Witheringon B, Foley A, Hardy R, Meylan A (2008) In-water sea turtle monitoring and research in Florida: review and recommendations. US Department of Commerce, NOAA Tech Memo NMFSOPR-38

Finn SA, Thompson WP, Shamblin BM, Nairn CJ, Godfrey $\mathrm{MH}$ (2016) Northernmost records of hawksbill sea turtle nests and possible trans-Atlantic colonization event. Mar Turtle Newsl 151:27-29

Garduño-Andrade M, Guzmán V, Miranda E, BriseñoDueñas R, Abreu-Grobois FA (1999) Increases in hawksbill turtle (Eretmochelys imbricata) nestings in the Yucatán Peninsula, Mexico, 1977-1996: data in support of successful conservation? Chelonian Conserv Biol 3: 286-295

Goodman Hall A, Avens L, Braun McNeill J, Wallace B, Goshe LR (2015) Inferring long-term foraging trends of individual juvenile loggerhead sea turtles using stable isotopes. Mar Ecol Prog Ser 537:265-276

* Gorham JC, Clark DR, Bresette MJ, Bagley DA and others (2014) Characterization of a subtropical hawksbill sea turtle (Eretmochelys imbricata) assemblage utilizing shallow water natural and artificial habitats in the Florida Keys. PLOS ONE 9:e114171

* Hart KM, Sartain AR, Fujisaki I, Pratt HL Jr, Morley D, Feeley MW (2012) Home range, habitat use, and migrations of hawksbill turtles tracked from Dry Tortugas National Park, Florida, USA. Mar Ecol Prog Ser 457:193-207

KHart KM, Sartain AR, Hillis-Starr ZM, Phillips B and others (2013) Ecology of juvenile hawksbills (Eretmochelys imbricata) at Buck Island Reef National Monument, US Virgin Islands. Mar Biol 160:2567-2580

Hawkes LA, McGowan A, Broderick AC, Gore S and others (2014) High rates of growth recorded for hawksbill sea turtles in Anegada, British Virgin Islands. Ecol Evol 4: 1255-1266

Herren RM, Bagley DA, Bresette MJ, Holloway-Adkins KG, Clark D, Witherington BE (2018) Sea turtle abundance and demographic measurements in a marine protected area in the Florida Keys, USA. Herpetol Conserv Biol 13: $224-239$

Holl CM, Villareal TA, Payne CD, Clayton TD, Hart C, Montoya JP (2007) Trichodesmium in the western Gulf of Mexico: ${ }^{15} \mathrm{~N}_{2}$-fixation and natural abundance stable isotopic evidence. Limnol Oceanogr 52:2249-2259

Jochum KP, Weis U, Stoll B, Kuzmin D and others (2011) Determination of reference values for NIST SRM 610617 glasses following ISO guidelines. Geostand Geoanal Res 35:397-429

Kamel SJ (2013) Vegetation cover predicts temperature in nests of the hawksbill sea turtle: implications for beach management and offspring sex ratios. Endang Species Res 20:41-48

Kawazu I, Kino M, Maeda K, Teruva H (2015) Age and body size of captive hawksbill turtles at the onset of follicular development. Zoo Biol 34:178-182 
Kendall WL, Stapleton S, White GC, Richardson JI, Pearson KN, Mason P (2019) A multistate open robust design: population dynamics, reproductive effort, and phenology of sea turtles from tagging data. Ecol Monogr 89: e01329

Kent AJR, Ungerer CA (2006) Analysis of light lithophile elements ( $\mathrm{Li}, \mathrm{Be}, \mathrm{B})$ by laser ablation ICP-MS: comparison between magnetic sector and quadrupole ICP-MS. Am Mineral 91:1401-1411

Koch PL, Fogel ML, Tuross N (1994) Tracing the diets of fossil animals using stable isotopes. In: Lajtha $\mathrm{K}$, Michener $\mathrm{RH}$ (eds) Stable isotopes in ecology and environmental science. Blackwell, Boston, MA, p 63-92

Krueger BH, Chaloupka MY, Leighton PA, Dunn JA, Horrocks JA (2011) Somatic growth rates for a hawksbill turtle population in coral reef habitat around Barbados. Mar Ecol Prog Ser 432:269-276

Lagueux C, Campbell CL, McCoy WA (2003) Nesting and conservation of the hawksbill turtle, Eretmochelys imbricata, in the Pearl Cays, Nicaragua. Chelonian Conserv Biol 4:588-602

León YM, Diez CE (1999) Population structure of hawksbills on a foraging ground in the Dominican Republic. Chelonian Conserv Biol 3:230-236

Levasseur KE, Stapleton SP, Quattro JM (2020) Precise natal homing and an estimate of age at sexual maturity in hawksbill turtles. Anim Conserv, doi:10.1111/acv.12657

Limpus CJ, Miller JD (2008) Australian hawksbill turtle population dynamics project. Report. Queensland Government Environmental Protection Agency, Queensland Parks and Wildlife Service. http://akepa.hpa.edu/ mrice/ turtle/Articles\%20of\%20interest/australia/Australian_ Hawksbill_Turtle_Population_Dynamics_Project.pdf

Llamas I, Flores EE, Abrego ME, Seminoff JA and others (2017) Distribution, size range and growth rates of hawksbill turtles at a major foraging ground in the eastern Pacific Ocean. Lat Am J Aquat Res 45:597-605

Meylan A (1988) Spongivory in hawksbill turtles: a diet of glass. Science 239:393-395

Meylan AB, Donnelly M (1999) Status justification for listing the hawksbill turtle (Eretmochelys imbricata) as critically endangered on the 1996 IUCN Red List of Threatened Animals. Chelonian Conserv Biol 3:200-234

Meylan A, Redlow A (2006) Eretmochelys imbricatahawksbill turtle. Chelonian Res Monogr 3:105-127

Meylan PA, Meylan AB, Gray JA (2011) The ecology and migrations of sea turtles. 8. Tests of the developmental habitat hypothesis. Bull Am Mus Nat Hist 2011(357): $1-70$

Miller JA (2007) Scales of variation in otolith elemental chemistry of juvenile staghorn sculpin (Leptocottus armatus) in three Pacific Northwest estuaries. Mar Biol 151:483-494

Moncada F, Daniel C, Nodarse G, Revuelta O and others (2020) Hawksbill turtle (Eretmochelys imbricata) tagged as a juvenile in Cuba observed nesting in Barbados 14 years later. Mar Turtle Newsl 160:23-25

Montoya JP (2007) Natural abundances of ${ }^{15} \mathrm{~N}$ in the marine environment. In: Michener RH, Lajtha K (eds) Stable isotopes in ecology and environmental science, 2nd edn. Blackwell Publishing, Malden, MA, p 176-201

Mortimer JA, Donnelly M (IUCN SSC Marine Turtle Specialist Group) (2008) Hawksbill turtle. Eretmochelys imbricata. The IUCN Red List of Threatened Species 2008: e.T8005A12881238. https://dx.doi.org/10.2305/IUCN.UK. 2008.RLTS.T8005A12881238.en
Mortimer JA, Collie J, Jupiter T, Chapman R, Liljevik A, Betsy B (2003) Growth rates of immature hawksbills (Eretmochelys imbricata) at Aldabra Atoll, Seychelles (Western Indian Ocean). In: Seminoff JA (compiler) Proc 22nd Annu Symp Sea Turtle Biol Conserv NOAA Tech Memo NMFS-SEFSC-503, p 247-248

* Mulholland MR, Bernhardt PW, Heil CA, Bronk DA, O'Neil JM (2006) Nitrogen fixation and release of fixed nitrogen by Trichodesmium spp. in the Gulf of Mexico. Limnol Oceanogr 51:1762-1776

NMFS, USFWS (National Marine Fisheries Service, US Fish and Wildlife Service) (2013) Hawksbill sea turtle (Eretmochelys imbricata) 5-year review: summary and evaluation. https://repository.library.noaa.gov/view/noaa/17041

NRC (National Research Council) (2010) Assessment of sea-turtle status and trends: integrating demography and abundance. National Academies Press, Washington, DC

Office of National Marine Sanctuaries (2008) Flower Garden Banks National Marine Sanctuary Condition Report 2008. US Department of Commerce, National Oceanic and Atmospheric Administration, Office of National Marine Sanctuaries, Silver Spring, MD

* Omeyer LCM, Godley BJ, Broderick AC (2017) Growth rates of adult sea turtles. Endang Species Res 34:357-371

Ordoñez Espinosa C, Meylan AB, Meylan PA, Peterson I, Diez CE, van Dam RP (2010) Hawksbill tagged as a juvenile in Puerto Rico found nesting in Panama 15 years later. Mar Turtle Newsl 127:25

* Peek S, Clementz MT (2012) Sr/Ca and Ba/Ca variations in environmental and biological sources: a survey of marine and terrestrial systems. Geochim Cosmochim Acta 95: 36-52

* Pinheiro J, Bates D, DebRoy S, Sarkar D, R Core Team (2017) nlme: linear and nonlinear mixed effects models. R package version 3.1-131. https://cran.r-project.org/web/ packages/nlme/index.html

*Post DM, Layman CA, Arrington DA, Takimoto G, Quattrochi J, Montaña CG (2007) Getting to the fat of the matter: models, methods and assumptions for dealing with lipids in stable isotope analyses. Oecologia 152:179-189

Proietti MC, Reisser J, Secchi ER (2012) Foraging by immature hawksbill sea turtles at Brazilian islands. Mar Turtle Newsl 135:4-6

* Putman NF, Abreu-Grobois FA, Broderick A, Ciofi C and others (2014) Numerical dispersal simulations and genetics help explain the origin of hawksbill sea turtles in Ascension Island. J Exp Mar Biol Ecol 450:98-108

R Core Team (2019) R: a language and environment for statistical computing. R Foundation for Statistical Computing, Vienna

Rabalais SC, Rabalais NN (1980) The occurrence of sea turtles on the south Texas coast. Contrib Mar Sci 23: $123-129$

* Radabaugh KR, Peebles EB (2014) Multiple regression models of $\delta^{13} \mathrm{C}$ and $\delta^{15} \mathrm{~N}$ for fish populations in the eastern Gulf of Mexico. Cont Shelf Res 84:158-168

Ramirez MD, Avens L, Seminoff JA, Goshe LR, Heppell SS (2015) Patterns of loggerhead turtle ontogenetic shifts revealed through isotopic analysis of annual skeletal growth increments. Ecosphere 6:244

Ramirez MD, Miller JA, Parks E, Avens L and others (2019) Reconstructing sea turtle ontogenetic habitat shifts through trace element analysis of bone tissue. Mar Ecol Prog Ser 608:247-262 
Ramirez MD, Avens L, Goshe LR, Snover ML, Cook M, Heppell SS (2020a) Regional variation in Kemp's ridley sea turtle diet composition and its potential relationship with somatic growth. Front Mar Sci 7:253

Ramirez MD, Avens L, Goshe LR, Snover ML, Cook M, Haas HL, Heppell SS (2020b) Regional environmental drivers of Kemp's ridley sea turtle somatic growth variation. Mar Biol 167:146

Santos AJB, Bellini C, Bortolon LFW, Outerbridge B and others (2019) Long-range movements and growth rates of Brazilian hawksbill turtles: insights from a flipper-tagging program. Chelonian Conserv Biol 18:75-81

Scales KL, Lewis JA, Lewis JP, Castellanos D, Godley BJ, Graham RT (2011) Insights into habitat utilization of the hawksbill turtle, Eretmochelys imbricata (Linnaeus, 1766) using acoustic telemetry. J Exp Mar Biol Ecol 407:122-129

Selby TH, Hart KM, Smith BJ, Pollock CG, Hillis-Starr Z, Oli MK (2019) Juvenile hawksbill residency and habitat use within a Caribbean marine protected area. Endang Species Res 40:53-64

Shaver DJ (1994) Relative abundance, temporal patterns, and growth of sea turtles at the Mansfield Channel, Texas. J Herpetol 28:491-497

Shaver DJ (1998) Sea turtle strandings along the Texas Coast, 1980-94. In: Zimmerman R (ed) Characteristics and causes of Texas marine strandings. US Department of Commerce, NOAA Tech Rep NMFS 143, p 57-72

Shaver DJ, Frandsen HR (2019) Eretmochelys imbricata (hawksbill sea turtle). Nesting. Herpetol Rev 50:350-351

Snover ML (2002) Growth and ontogeny of sea turtles using skeletochronology: methods, validation, and application to conservation. $\mathrm{PhD}$ dissertation, Duke University, Durham, NC

Snover ML, Hohn AA (2004) Validation and interpretation of annual skeletal marks in loggerhead (Caretta caretta) and Kemp's ridley (Lepidochelys kempii) sea turtles. Fish Bull 102:682-692

Snover ML, Avens L, Hohn AA (2007) Back-calculating length from skeletal growth marks in loggerhead sea turtles Caretta caretta. Endang Species Res 3:95-104

Snover ML, Hohn AA, Crowder LB, Macko SA (2010) Combining stable isotopes and skeletal growth marks to detect habitat shifts in juvenile loggerhead sea turtles Caretta caretta. Endang Species Res 13:25-31

Snover ML, Balazs GH, Murakawa SKK, Hargrove SK, Rice MR, Seitz WA (2013) Age and growth rates of Hawaiian hawksbill turtles (Eretmochelys imbricata) using skeletochronology. Mar Biol 160:37-46

Turner Tomaszewicz CN, Seminoff JA, Avens L, Goshe LR and others (2015) Age and residency duration of loggerhead turtles at a North Pacific bycatch hotspot using skeletochronology. Biol Conserv 186:134-142

Turner Tomaszewicz CN, Seminoff JA, Peckham SH, Avens L, Kurle CM (2017) Intrapopulation variability in the tim-

Editorial responsibility: Paolo Casale,

Pisa, Italy

Reviewed by: 2 anonymous referees ing of ontogenetic habitat shifts in sea turtles revealed using $\delta^{15} \mathrm{~N}$ values from bone growth rings. J Anim Ecol 86:694-704

* Turner Tomaszewicz CN, Seminoff JA, Avens L, Goshe LR, Rguez-Baron JM, Peckham SH, Kurle CM (2018) Expanding the coastal forager paradigm: long-term pelagic habitat use by green turtles Chelonia mydas in the eastern Pacific Ocean. Mar Ecol Prog Ser 587:217-234

* Van Buskirk J, Crowder LB (1994) Life-history variation in marine turtles. Copeia 1994:66-81

*Van Dam RP, Diez CE (1998) Home range of immature hawksbill turtles (Eretmochelys imbricata (Linnaeus)) at two Caribbean islands. J Exp Mar Biol Ecol 220:15-24

*Van Dam RP, Diez CE, Balazs GH, Colón LA, McMillan WO, Schroeder B (2008) Sex-specific migration patterns of hawksbill turtles breeding at Mona Island, Puerto Rico. Endang Species Res 4:85-94

Vander Zanden HB, Tucker AD, Hart KM, Lamont MM and others (2015) Determining origin in a migratory marine vertebrate: a novel method to integrate stable isotopes and satellite tracking. Ecol Appl 25:320-335

*WWallace BP, DiMatteo AD, Hurley BJ, Finkbeiner EM and others (2010) Regional management units for marine turtles: a novel framework for prioritizing conservation and research across multiple scales. PLOS ONE 5:e15465

*Weber SB, Weber N, Godley BJ, Pelembe T, Stroud S, Williams N, Broderick AC (2017) Ascension Island as a mid-Atlantic developmental habitat for juvenile hawksbill turtles. J Mar Biol Assoc UK 97:813-820

*Wildermann NE, Gredzens C, Avens L, Barrios-Garrido HA and others (2018) Informing research priorities for immature sea turtles through expert elicitation. Endang Species Res 37:55-76

Witherington B, Hirama S, Hardy R (2012) Young sea turtles of the pelagic Sargassum-dominated drift community: habitat use, population density, and threats. Mar Ecol Prog Ser 463:1-22

Witzell WN (1983) Synopsis of biological data on the hawksbill turtle, Eretmochelys imbricata (Linnaeus, 1766). FAO Fish Synop 137. FAO, Rome

Wood SN (2006) Generalized additive models: an introduction with R. CRC Press, Boca Raton, FL

Wood LD, Hardy R, Meylan PA, Meylan AB (2013) Characterization of a hawksbill turtle (Eretmochelys imbricata) foraging aggregation in a high-latitude reef community in southeastern Florida, USA. Herpetol Conserv Biol 8: 258-275

*Wood LD, Brunnick B, Milton SL (2017) Home range and movement patterns of subadult hawksbill sea turtles in southeast Florida. J Herp 51:58-67

Zug GR, Wynn AH, Ruckdeschel C (1986) Age determination of loggerhead sea turtles, Caretta caretta, by incremental growth marks in the skeleton. Smithson Contrib Zool 427:1-34

Submitted: December 17, 2020

Accepted: March 8, 2021

Proofs received from author(s): May 28, 2021 